\title{
Maillard-Type Protein-Polysaccharide Conjugates and Electrostatic Protein-Polysaccharide Complexes as Delivery Vehicles for Food Bioactive Ingredients: Formation, Types, and Applications
}

\author{
Xiaohong Sun ${ }^{1,2}{ }^{\mathbb{D}}$, Hao Wang ${ }^{1}$, Shengnan $\mathrm{Li}^{1}$, Chunli Song ${ }^{1}$, Songyuan Zhang ${ }^{3}$, Jian Ren ${ }^{1, *}$ \\ and Chibuike C. Udenigwe ${ }^{2,4}$ (D)
}

check for

updates

Citation: Sun, X.; Wang, H.; Li, S.; Song, C.; Zhang, S.; Ren, J.; Udenigwe, C.C. Maillard-Type Protein-Polysaccharide Conjugates and Electrostatic

Protein-Polysaccharide Complexes as Delivery Vehicles for Food Bioactive Ingredients: Formation,

Types, and Applications. Gels 2022, 8 , 135. https://doi.org/10.3390/ gels8020135

Academic Editors: Mohammad Rezaul Islam Shishir and Naymul Karim

Received: 5 January 2022

Accepted: 18 February 2022

Published: 21 February 2022

Publisher's Note: MDPI stays neutral with regard to jurisdictional claims in published maps and institutional affiliations.

Copyright: (C) 2022 by the authors. Licensee MDPI, Basel, Switzerland. This article is an open access article distributed under the terms and conditions of the Creative Commons Attribution (CC BY) license (https:// creativecommons.org/licenses/by/ $4.0 /)$
1 College of Food and Biological Engineering, Qiqihar University, Qiqihar 161006, China; xs7@ualberta.ca (X.S.); wh0000730@163.com (H.W.); 1sn_xixi@163.com (S.L.); songchunli@qqhru.edu.cn (C.S.)

2 Faculty of Health Sciences, School of Nutrition Sciences, University of Ottawa, Ottawa, ON K1H 8M5, Canada; cudenigw@uottawa.ca

3 Zhejiang SDM Research Institute, Hangzhou 310020, China; songyuanzhang1995@163.com

4 Department of Chemistry and Biomolecular Sciences, University of Ottawa, Ottawa, ON K1N 6N5, Canada

* Correspondence: renjian1970789@163.com

\begin{abstract}
Due to their combination of featured properties, protein and polysaccharide-based carriers show promising potential in food bioactive ingredient encapsulation, protection, and delivery. The formation of protein-polysaccharide complexes and conjugates involves non-covalent interactions and covalent interaction, respectively. The common types of protein-polysaccharide complex/conjugate-based bioactive ingredient delivery systems include emulsion (conventional emulsion, nanoemulsion, multiple emulsion, multilayered emulsion, and Pickering emulsion), microcapsule, hydrogel, and nanoparticle-based delivery systems. This review highlights the applications of protein-polysaccharide-based delivery vehicles in common bioactive ingredients including polyphenols, food proteins, bioactive peptides, carotenoids, vitamins, and minerals. The loaded food bioactive ingredients exhibited enhanced physicochemical stability, bioaccessibility, and sustained release in simulated gastrointestinal digestion. However, limited research has been conducted in determining the in vivo oral bioavailability of encapsulated bioactive compounds. An in vitro simulated gastrointestinal digestion model incorporating gut microbiota and a mucus layer is suggested for future studies.
\end{abstract}

Keywords: Maillard reaction; electrostatic complex; stability; sustained release; bioaccessibility; mucus layer

\section{Introduction}

Food bioactive ingredients are compounds that exert health-promoting properties via modulating physiological or cellular activities, such as antioxidant, anti-inflammatory, anticancer, and immunomodulating activities [1]. Hence, development of functional foods by incorporating bioactive compounds is a promising strategy to improve human nutrition and health. However, it is challenging to simply add bioactive ingredients into food product matrices owing to the poor water solubility, low physicochemical stability, off-flavor, and limited bioaccessibility and bioavailability of many bioactive ingredients [1].

Designing suitable delivery systems for bioactive ingredients has proven to be an effective approach to overcome these shortcomings. As the two abundant food macromolecules, proteins and polysaccharides have been widely used to fabricate carriers for encapsulating bioactive ingredients [2]. Nevertheless, proteins and polysaccharides have their respective strengths and weaknesses as carrier materials. Proteins are effective at generating small emulsion droplets, but have relatively poor stability to environmental stimuli 
such as $\mathrm{pH}$, salt, thermal, and freezing treatments. Conversely, polysaccharides possess desirable stability against environmental stresses, but have relatively poor emulsifying activity [3]. As such, the formation of protein-polysaccharide complexes would potentially combine their featured properties to overcome the shortcomings. Generally speaking, protein-polysaccharide interactions include both covalent interaction and non-covalent interactions, which can be classified into covalent protein-polysaccharide conjugates and non-covalent protein-polysaccharide complexes, respectively [1].

Covalent protein-polysaccharide conjugation can be formed using enzymatic crosslinking technique (i.e., oxidases and transglutaminase), the chemical cross-linking method (i.e., genipin, glutaraldehyde, and poly(ethylene glycol) dibutyraldehyde), and the Maillard reaction [1]. The Maillard reaction is one of the most well documented methods for preparing covalent protein-polysaccharide conjugates $[4,5]$. Different non-covalent interactions are responsible for the formation of protein-polysaccharide complexes depending on the distinct physicochemical properties of these biopolymers and environmental factors, such as electrostatic interactions, hydrophobic interactions, hydrogen bonding, and steric exclusion. Electrostatic interactions driven by enthalpy are a major driving force for the formation of non-covalent complexes when proteins and polysaccharides carry opposite charges [6].

In previous years, development of Maillard-type protein-polysaccharide conjugates or electrostatic complexes as delivery vehicles for food bioactive ingredients has received increasing attention [1,6]. To provide a comprehensive understanding of current research advances, this review discusses the formation and characterization of Maillardtype protein-polysaccharide conjugates and electrostatic complexes, the common types of protein-polysaccharide complex/conjugate-based delivery systems, and the applications of protein-polysaccharide complex/conjugate in encapsulation and delivery of polyphenols, food proteins, bioactive peptides, carotenoids, vitamins, and minerals.

\section{Formation and Characterization of Maillard-Type Protein-Polysaccharide Conjugates and Electrostatic Complexes}

The chemistry behind the formation of Maillard-type protein-polysaccharide conjugates and electrostatic protein-polysaccharide complexes is discussed in this section. In general, a wide range of protein sources (e.g., soy protein isolates, whey proteins, and egg white proteins) and polysaccharides (e.g., chitin, pectin, and soy hull hemicelluloses) have been applied in the production of protein-polysaccharide conjugates and complexes. The major functional properties, such as solubility, thermal stability, emulsifying and stabilizing properties, rheological and structural features, are also discussed.

\subsection{Maillard-Type Protein-Polysaccharide Conjugates}

2.1.1. Formation of Covalent Protein-Polysaccharide Conjugates by Maillard Reaction

The Maillard reaction was first reported by French chemist Louis Maillard in 1912 [7]. The Maillard reaction occurs naturally under controlled $\mathrm{pH}$, reaction time, temperature, and moisture conditions, and involves a series of non-enzymatic browning reactions. It starts with covalent bonding between reducing ends of carbohydrates and amino groups of proteins, especially between the $\varepsilon$-amino group of lysine residue and the carbonyl group of reducing carbohydrates $[4,8,9]$. The Maillard reaction is generally divided into early, intermediate, and final stages [4]. All three stages can occur simultaneously and are correlative [10]. Current understanding of the chemical mechanisms of formed compounds in each stage has been reviewed recently in other works $[4,9]$ and, thus, was excluded from this review.

The most widely applied method to synthesize Maillard-type protein-polysaccharide conjugates is heat treatment, either in dry state (dry-heating method) or in aqueous solution (wet-heating method) [4]. The dry-heating method involves the heating of freeze-dried protein and polysaccharide mixture under controlled temperature (usually ranging from $40-80{ }^{\circ} \mathrm{C}$ ) and relative humidity ( $65 \%$ or $79 \%$ most commonly used) for a duration varying 
from hours to weeks, which are considered as mild reaction conditions [4]. The dry-heating method has some drawbacks; it is time-consuming, costly, and with limited production scale [11]. In the wet-heating method, aqueous solution of proteins and polysaccharides is heated at a specific temperature but for a shorter time compared to the dry-heating method. Possible adverse effects during wet heating at increased temperatures are low grafting degrees with polysaccharides due to protein denaturation and polymerization [4,12]. A higher grafting degree with polysaccharides is usually positively correlated with the stronger encapsulation ability of hydrophobic bioactive compounds such as curcumin [12]. He et al. [12] developed a novel method called continuous cyclic reaction (7 cycles of low-speed agitation at $60^{\circ} \mathrm{C}$ for $20 \mathrm{~min}$ and water-bath heating at $83^{\circ} \mathrm{C}$ for $10 \mathrm{~min}$ ) in order to increase the grafting degree of resulting SPI-dextran conjugates.

Maillard-type protein-polysaccharide conjugates exerted antimicrobial, antioxidant, and anti-antigenicity activities $[13,14]$. Besides these beneficial effects, advanced glycation end-products were associated with some detrimental effects including mutagenic, carcinogenic, and cytotoxic properties [4]. Optimization of reaction parameters (i.e., time, $\mathrm{pH}$, water activity, and temperature) may prevent the generation of the antinutritional and toxic compounds by controlling the reaction progress [15]. For example, egg whitegalactomannan conjugates were generated in a controlled dry state ( $79 \%$ relative humidity) at $60{ }^{\circ} \mathrm{C}$ for two weeks, and their safety was confirmed by mammalian cell proliferation assay [16]. By and large, glycated proteins fabricated by the Maillard reaction are safer than chemically modified proteins [15]. Therefore, Maillard-type protein-polysaccharide conjugates have the potential to be safely utilized in food products.

\subsubsection{Characterization of Maillard-Type Protein-Polysaccharide Conjugates}

Various techniques have been used to assess the formation and physicochemical properties of protein-polysaccharide conjugates, such as molecular weight profile, particle size distribution, browning index, free amino groups, and structural characteristics [4]. Specifically, sodium dodecyl sulfate polyacrylamide gel electrophoresis (SDS-PAGE) is commonly used to detect molecular weight changes after conjugate formation. For instance, the occurrence of a protein band with a high molecular weight (on the top of separating gel) indicated the formation of $\beta$-lactoglobulin-gum Acacia Seyal conjugates [17]. Mass spectrometry has also been applied to confirm conjugate formation by analyzing the increment in molecular mass [4]. Desorption ionization-time of flight mass spectrometry (MALDI-TOF MS) analysis was used to demonstrate that bovine serum albumin (BSA) was glycated with chitin oligosaccharides at $43 \%$ relative humidity and $60{ }^{\circ} \mathrm{C}$ after 6 and $12 \mathrm{~h} \mathrm{[18].} \mathrm{In} \mathrm{addition,} \mathrm{the} \mathrm{particle} \mathrm{size} \mathrm{distribution} \mathrm{of} \mathrm{protein-polysaccharide} \mathrm{conjugates} \mathrm{is}$ often determined by dynamic light scattering (DLS). DLS measurements showed that the average particle size of lysozyme-pullulan conjugates was 3.5-fold higher and the range of particle size distribution was broader compared to that of untreated lysozyme [19].

Since browning always occurs during the Maillard reaction, a browning index can be used to determine the extent of the reaction between proteins and polysaccharides by measuring absorbance of the conjugates at $420 \mathrm{~nm}[17,20,21]$. A free amino group of protein-polysaccharide conjugates is used as an indicator of degree of substitution during the Maillard reaction [22], and is usually determined by o-phthaldialdehyde (OPA) assay or 2,4,6-trinitrobenzenesulfonic acid (TNBS) method. When $\beta$-lactoglobulin and gum Acacia seyal were reacted at $60{ }^{\circ} \mathrm{C}$ and $79 \%$ relative humidity, $\sim 30 \%$ decrease of free amino groups was observed after $12 \mathrm{~h}$ due to conjugation with the polysaccharide [17].

The secondary structures of conjugates are commonly analyzed by circular dichroism (CD) and Fourier-transform infrared spectroscopy (FTIR). CD spectroscopy revealed that the secondary structures of lysozyme changed after conjugation to pullulan. Compared with native lysozyme, the conjugates had reduced $\alpha$-helical structure (from 33\% to $24 \%$ ) and increased $\beta$-turn (from $2 \%$ to $9 \%$ ) and random coil (from $29 \%$ to $33 \%$ ) [19]. Similarly, substantial changes were reported in the CD spectrum of WPI-polysaccharide conjugates compared to native WPI [22]. FTIR is another relevant technique for investigating the 
structure and interaction of protein-polysaccharide conjugates based on alterations in the spectra, such as the appearance of new peaks and changes in the peak location and intensity [23]. FTIR analysis suggested that conjugation of soybean protein isolate with glucose or chitosan oligosaccharide decreased the contents of $\alpha$-helix and $\beta$-sheet with a concomitant increase in $\beta$-turn and random coil [24]. Lastly, changes in protein conformations due to conjugation with polysaccharides could be monitored by measuring the intrinsic fluorescence of Trp [19]. The occurrence of a red shift phenomenon may result from a more hydrophilic microenvironment surrounding protein molecules after glycosylation, which leads to alterations in protein conformations [25]. Reduction of fluorescence intensity after conjugation was observed in several studies, which has been attributed to protein conformational changes and the strong steric-hindrance effect of the polysaccharide chain that shields the fluorescence signal of Trp residues $[19,23,26]$.

\subsubsection{Functional Properties of Maillard-Type Protein-Polysaccharide Conjugates Solubility and Thermal Stability}

Solubility is one of the most important factors that determine the other functional properties of biopolymers, such as thermal stability and emulsifying properties [25]. Generally, the water solubility of Maillard-type protein-polysaccharide conjugates could be significantly enhanced compared to untreated proteins [4]. Ma et al. [25]. reported that the solubility of soy protein isolate (SPI)-pectin conjugates was significantly improved compared to native SPI. Conjugates of whey proteins ( $\beta$-lactoglobulin, $\alpha$-lactalbumin, and BSA) and dextran (molecular weight of 10 and $20 \mathrm{kDa}$ ) exhibited increased solubility at the isoelectric point of the crude proteins [27]. The increased solubility was mainly attributed to the grafted hydrophilic polysaccharide moieties, as well as the reduced intermolecular aggregation of protein molecules owing to the steric-repulsion effect induced by the polysaccharide $[8,25]$. However, contradictory results have been reported. Reduction in the solubility of egg white protein-pectin conjugates was observed with increased Maillard reaction time [28]. The biochemical complexity of proteins, different natures of polysaccharides, and formation of intermolecular disulfide bonds during conjugation may result in this discrepancy [4].

Improved thermal stability of glycosylated proteins produced by the Maillard reaction has been widely reported [4,29]. For instance, soy hull hemicelluloses-SPI conjugates exhibited a higher thermal stability compared to the individual biopolymer which was determined by the thermal gravimetric analysis. Specifically, the conjugates containing the SPI contents from $20 \%$ to $60 \%$ showed higher thermal stability. The authors suggested that the increased protein content in the conjugates was positively associated with the enhanced thermal stability [29].

\section{Emulsifying and Stabilizing Properties}

Among their functional properties, the emulsifying properties of protein-polysaccharide conjugates are the most extensively investigated [4]. It is generally reported that proteinpolysaccharide conjugates possess better emulsifying properties than crude proteins at both low and neutral $\mathrm{pHs}$, particularly at a $\mathrm{pH}$ close to the isoelectric point [8]. Critical parameters, such as the molecular weight and structure of the polysaccharide, reaction time, and ratio of protein and polysaccharide, play important roles in the emulsifying and stabilizing properties of the conjugates [4,8]. For example, with a reaction time of $12 \mathrm{~h}$, milk protein isolate/ $\mathrm{K}$-carrageenan conjugates at a ratio of $1: 1$ at $65^{\circ} \mathrm{C}$ were utilized to effectively produce a stable oil-in-water emulsion during storage at $40{ }^{\circ} \mathrm{C}$ for $2 \mathrm{~d}$ [30]. Moreover, the balanced amphiphilic nature of protein-polysaccharide conjugates is indispensable for enhancing their emulsifying properties [4].

Ma et al. [25]. recently demonstrated the emulsifying activity index of the SPI-pectin conjugates had a 3-fold increase compared with the native SPI [25]. The improved emulsifying activity was attributed to inhibition of protein-protein interactions resulting from glycosylation [31]. Ultrasound treatment contributes to further enhancement in the emulsi- 
fying activity of conjugates [31,32]. The increased degree of graft, surface hydrophobicity, and extended spatial conformations of proteins induced by ultrasound were responsible for the improved emulsifying properties [32]. In contrast, emulsifying properties were shown to decrease in BSA-glucose and BSA-mannose conjugates compared to BSA, partly due to the decreased surface hydrophobicity and alterations in conformational flexibility [33].

Likewise, the emulsifying stability of protein-polysaccharide conjugates is higher than that of native proteins $[25,29,34]$. Compared to native SPI, SPI-citrus pectin conjugates prepared by dry-heating conditions showed a 2 -fold increase in the emulsifying stability index [25]. This possibly resulted from the strong steric-hindrance effect from polysaccharides, which effectively prevented the oil droplets from re-coalescence [31,34]. Moreover, ultrasound-assisted reaction increased the emulsifying stability index 2-fold compared to SPI-citrus pectin conjugates formed by the traditional wet-heating method [32]. This was mainly owing to the fact that ultrasound treatment changes the surface hydrophobicity and secondary structures of protein molecules [31]. On the other hand, mild ultrasound treatment $(100 \mathrm{~W})$ favored the control of the Maillard reaction to produce myofibrillar protein-dextran conjugates with enhanced emulsifying ability and stability when compared to conjugates generated with high-intensity ultrasound (300 W) [35].

\subsection{Electrostatic Protein-Polysaccharide Complexes}

\subsubsection{Formation of Electrostatic Protein-Polysaccharide Complexes}

As shown in Figure 1a, a biopolymer mixture of protein and polysaccharide may result in different phase systems, including co-soluble polymers, associative phase separation (complex coacervation) and segregative phase separation (thermodynamic incompatibility), which highly depends on factors such as $\mathrm{pH}$, ionic strength, biopolymer concentration, and protein/polysaccharide ratio [36]. Biopolymers are co-soluble and remain stable in dilute solutions due to the dominating effects of mixing entropy [36,37]. However, the mixture has a tendency to be unstable with an increase in biopolymer concentration. This may lead to two phase behaviors that largely depend upon the electrostatic interaction between biopolymers [36]. When proteins and polysaccharides carry a similar net charge, segregative phase behavior (separation into protein-rich phase and polysaccharide-rich phase) may occur due to electrostatic repulsion [36]. On the other hand, electrostatic attraction results in the occurrence of associative phase behavior (complex coacervation) when two biopolymers exhibit the opposite net charge [37]. Complex coacervation is a liquid-liquid phase separation phenomenon where one phase is rich in biopolymers and the other phase is rich in solvent. Coacervation contributes to the formation of electrostatic complexes between oppositely charged proteins and polysaccharides [38]. Overall, the main driving force for the complexation is electrostatic interaction when proteins and polysaccharides carry opposite charges.

The formed complexes can be either soluble or insoluble, depending on various parameters, especially $\mathrm{pH}$ (depicted in Figure 1b) [38,39]. According to the distinct structure-forming characteristics of complexes, four critical $\mathrm{pH}$ values have been defined [40]. The first critical $\mathrm{pH}$ value $\left(\mathrm{pH}_{\mathrm{c}}\right)$ has been regarded as the onset of the formation of soluble complexes, which is the first detectable interaction. The $\mathrm{pH}_{\mathrm{c}}$ of electrostatic protein-polysaccharide complexes is generally near or below the isoelectric point $(\mathrm{pI})$ of the protein since all naturally occurring polysaccharides are neutral or acidic except chitosan $[40,41]$. When $\mathrm{pH}$ is higher than $\mathrm{pH}_{\mathrm{c}}$, proteins and polysaccharides are co-soluble molecules in solution [40]. With a decrease in $\mathrm{pH}$ from $\mathrm{pH}_{\mathrm{c}}$, solubility of the complexes decreases and they start to aggregate into insoluble forms due to charge neutralization at the second critical $\mathrm{pH}\left(\mathrm{pH}_{\varphi 1}\right)$, which results in a sharp increase in turbidity. The maximum turbidity value is reached at $\mathrm{pH}_{\mathrm{opt}}$, which is the electric neutral points of proteins and polysaccharides. As the $\mathrm{pH}$ reduces further and reaches the $\mathrm{pH}_{\varphi 2}$, the complexes disassociate into individual biopolymers because reactive sites on the polysaccharide chains are more protonated [40,42-44]. Taking the electrostatic complexes between BSA and sodium 
alginate as an example, the critical $\mathrm{pH}$ values $\left(\mathrm{pH}_{\mathrm{c}}, \mathrm{pH}_{\varphi 1}, \mathrm{pH}_{\mathrm{opt}}\right.$, and $\left.\mathrm{pH}_{\varphi 2}\right)$ were 4.8, 4.2, 2.8 and 1.8 , respectively [45].

(a)

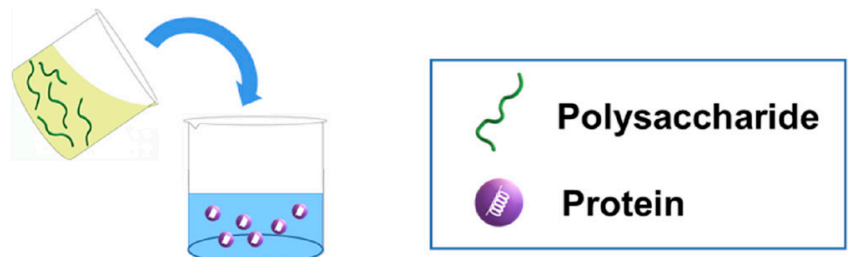

(b)

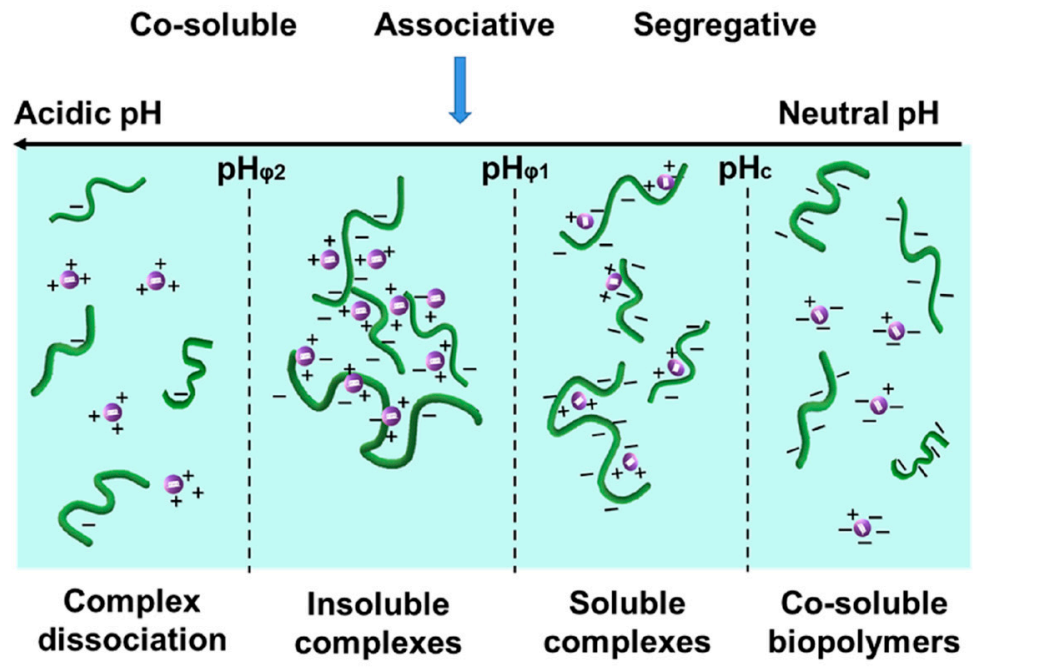

Figure 1. (a) Formation of different phase systems between proteins and polysaccharides, including co-soluble biopolymers, associative phase separation (complex coacervation), and segregative phase separation (thermodynamic incompatibility). (b) A schematic diagram of the transitions of protein-polysaccharide complexes induced by $\mathrm{pH}$ changes.

Besides $\mathrm{pH}$, other parameters that influence the formation of electrostatic proteinpolysaccharide complexes include ionic strength, charge density and distribution, polysaccharide type, biopolymer mixing ratio, and total concentration, temperature, and shearing rate. These factors have been extensively discussed in a recent review article [36] and, thus, further details will not be provided in this section. Moreover, protein-polysaccharide complexation is able to modify functional attributes compared to the individual component such as enhanced protein water solubility, emulsifying and stabilizing properties, as well as foaming ability and stability, which have been reviewed recently [36]. Thus, this review article mainly focused on their rheological and structural properties.

\subsubsection{Rheological and Structural Characteristics of Electrostatic}

Protein-Polysaccharide Complexes

Rheological properties of protein-polysaccharide complexes have gained increasing attention as they play important roles in determining the application of biopolymer complexes in food products [46]. To comprehensively understand the rheological properties of biopolymer complex coacervates, storage modulus $\left(G^{\prime}\right)$, loss modulus $\left(G^{\prime \prime}\right)$, loss tangent $(\tan \delta)$, critical value of stress $(\tau c)$ at the linear viscoelastic (LVE) region, fracture stress and strain, and crossover point need to be determined [47]. For example, a recent study used small amplitude oscillatory shear (SAOS) to extensively investigate the rheological 
properties of coacervates of rice bran protein-flaxseed gum [47]. Among these rheological parameters, $G^{\prime}$ and $G^{\prime \prime}$ are commonly measured in strain sweep or frequency sweep tests $[44,48]$.

Rheological characteristics of biopolymer complex coacervates are significantly influenced by environmental factors, such as $\mathrm{pH}$, protein/polysaccharide ratio, and ionic strength $[44,47,48]$. Hasanvanda and Rafeb [47] explored the influence of different $\mathrm{pH}$ values (3.3, 4.0, and 5.3) and protein/polysaccharide ratios (3:1, 6:1, and 9:1) on the rheological properties of rice bran protein-flaxseed gum coacervates. At $\mathrm{pH} 4.0$ and biopolymer ratio 9:1, the coacervates showed significantly higher structural strength ( $\left.\mathrm{G}^{\prime} \mathrm{LVE} 10,200 \mathrm{~Pa}\right)$ and loss modulus (G"LVE $2130 \mathrm{~Pa}$ ) as determined by amplitude sweep at $25^{\circ} \mathrm{C}$ [47]. In general, low salt concentration could cause salt-enhanced effects whereas the salt-reduced effect may occur with further increase in salt concentration [44]. Specifically, where the frequency ranged from 0.1 to $100 \mathrm{rad} / \mathrm{s}, \mathrm{G}^{\prime}$ values of $\beta$-lactoglobulin-pectin coacervates increased from $\sim 103 \mathrm{~Pa}$ to $105 \mathrm{~Pa}$ as the ionic strength increased from 0.01 to $0.21 \mathrm{M}$, while a further increase in ionic strength to $0.41 \mathrm{M}$ decreased the $\mathrm{G}^{\prime}$ values below $103 \mathrm{~Pa}$, because high salt concentration weakened the binding between $\beta$-lactoglobulin and pectin [44].

Furthermore, rheology data are often used to indicate the structures of proteinpolysaccharides coacervates. Specifically, a higher $G^{\prime}$ value than $G^{\prime \prime}$ of coacervates, such as rice bran protein-flaxseed gum coacervates and $\beta$-lactoglobulin-pectin coacervates, indicates the formation of highly interconnected gel-like structures [44,47]. Also, other analytical techniques are broadly used to investigate the microstructure of complex coacervates. Cryo-scanning electron microscopy (Cryo-SEM) study suggested that whey protein isolate (WPI)-Tremella fuciformis polysaccharide (TP) complexes exhibited more ordered structures than each of the two biopolymers [49]. CD spectroscopy indicated the $\alpha$-helix contents of WPI-TP complexes increased when compared to free WPI [49]. Likewise, Fourier transform infrared (FTIR) spectroscopy revealed that complexation with polysaccharides, including carrageenan, chitosan and sodium alginate, resulted in changes of the secondary structures of gelatin, i.e., the content of collagen-like triple helices in an $\alpha$-chain increased [50]. In 2018, Xu et al. [51] utilized small angle X-ray scattering (SAXS) and small angle neutron scattering (SANS) to understand the effects of polysaccharide charge pattern on the microstructures of $\beta$-lactoglobulin-pectin complex coacervates [51]. SAXS and SANS data indicated that compact primary particles are the major building blocks of complex coacervates, which are formed by overlapping $\beta$-lactoglobulin-binding pectin chains and bridged by protein-rich clusters. It was revealed that the size and distribution of the protein-rich clusters were influenced by the charge densities of pectin. More importantly, changes in the spatial arrangements of the primary particles could result in the complex coacervates transforming into precipitates. This study proposed the possibility of modifying the microstructure of protein-polysaccharide complex coacervates by utilization of polysaccharides with distinct charge patterns [51]. On the other hand, protein types could also influence the structures of complex coacervates. Compared to gelatin-gum arabic complex coacervates, soy proteingum arabic complex coacervates were less tight and structured with a characteristic length scale of $40 \mathrm{~nm}$ according to the Doi-Onuki model [46]. Jin et al. [52] recently reported that pulsed electric field (PEF) treatment changed the structures of $\alpha$-amylase-pectin electrostatic complexes to branched, ring, or circles-like shapes. To achieve these effects, it is possible the PEF technique modified the charge distribution of proteins and polysaccharides and subsequently influenced their electrostatic interactions and complex coacervation.

The chemistry behind the formation, commonly investigated structural characteristics and functional properties of Maillard-type protein-polysaccharide conjugates and electrostatic complexes discussed in this section were summarized in Table 1. 
Table 1. Comparison between Maillard-type protein-polysaccharide conjugates and electrostatic complexes.

\begin{tabular}{ccc}
\hline & $\begin{array}{c}\text { Maillard-Type } \\
\text { Protein-Polysaccharide Conjugates }\end{array}$ & $\begin{array}{c}\text { Electrostatic } \\
\text { Protein-Polysaccharide Complexes }\end{array}$ \\
\hline Formation & $\begin{array}{c}\text { Covalent bonding between reducing ends of } \\
\text { carbohydrates and amino groups of } \\
\text { proteins [4,8-10] }\end{array}$ & $\begin{array}{c}\text { Different phase systems between proteins and } \\
\text { polysaccharides, including co-soluble } \\
\text { biopolymers, complex coacervation, and } \\
\text { thermodynamic incompatibility [36] }\end{array}$ \\
\hline Structural characteristics & Secondary structures analyzed by CD [19,22] and \\
& FTIR [23,24] & $\begin{array}{c}\text { Secondary structures analyzed by CD [49] and } \\
\text { FTIR [50]; Microstructures analyzed by } \\
\text { Cryo-SEM [49], SAXS and SANS [51] }\end{array}$ \\
\hline Functional properties & $\begin{array}{c}\text { Enhanced functional properties compared to } \\
\text { native proteins: water solubility [25,27]; thermal } \\
\text { stability [29]; emulsifying property [25,31,32]; } \\
\text { emulsifying stability [25,29,34] }\end{array}$ & Rheological properties [46-48] \\
& &
\end{tabular}

\section{Different Types of Protein-Polysaccharide Complex- or Conjugate-Based Delivery Systems}

Protein-polysaccharide complexes or conjugates can be utilized as building blocks to fabricate delivery systems with more complex structures, such as emulsion, microcapsule, hydrogel, and nanoparticle-based delivery systems, which were discussed in this review [1]. Their common preparation methods, features and nature of the commonly encapsulated compounds are summarized in Table 2.

\subsection{Emulsion-Based Delivery Systems}

Protein-polysaccharide complexes or conjugates are widely used to fabricate emulsionbased delivery systems due to their enhanced emulsifying stability and better protection for the encapsulated compounds compared to individual proteins or polysaccharides [1,53]. Protein-polysaccharide complexes or conjugates are commonly used as emulsifiers to generate different types of emulsions including conventional emulsions, nanoemulsions, multiple emulsions, multilayered emulsions and Pickering emulsions [1].

\subsubsection{Conventional O/W Emulsions}

Conventional emulsions have the mean droplet radii in the range of $0.2-100 \mu \mathrm{m}$ (Figure 2a), which are thermodynamically unstable systems and prone to be optically turbid or opaque [54]. They can be formed using a high-shear mixer or a high-pressure homogenizer $[54,55]$. Oil-in-water $(\mathrm{O} / \mathrm{W})$ emulsions are commonly prepared for encapsulation of lipophilic nutraceutical compounds. Both protein-polysaccharide complexes and conjugates showed increased ability to stabilized the emulsion droplets against unfavorable environmental conditions $[55,56]$. For example, the $\mathrm{O} / \mathrm{W}$ emulsion prepared by casein-chitosan complexes possessed good stability in a broad $\mathrm{pH}$ range from 3.5 to 6.5 [55]. Additionally, the good stability of corn oil-in-water emulsions formulated with pea protein isolate-gum arabic conjugates was due to their small particle size, high surface charge and strong steric hindrance [56].

\subsubsection{Nanoemulsions $(\mathrm{O} / \mathrm{W})$}

Nanoemulsions typically have mean droplet radii that range from 50-200 nm (Figure 2a), and are thermodynamically stable isotropic systems that tend to be transparent or slightly opaque [54]. Nanoemulsions are developed for improving the delivery of bioactive compounds mainly due to their small droplet sizes and particle shapes dispersed in the continuous phase [57]. Nanoemulsions are fabricated using high-energy or low-energy methods. The high-energy method involves mechanical devices, such as high-speed blenders, high-pressure homogenizers, microfluidizers and ultrasonic probes. The low-energy methods include phase inversion and solvent mixing approaches [54]. Nanoemulsions produced from soy protein-soy polysaccharide complexes exhibited long-term stability at $\mathrm{pH}$ values of 2-8 and 
$0.2 \mathrm{M} \mathrm{NaCl}$ [58] or after heat treatment $\left(80{ }^{\circ} \mathrm{C}\right.$ for $\left.60 \mathrm{~min}\right)$ [59], indicating strong potential of the complexes to function as nanoscale carriers for delivering lipophilic bioactive ingredients.

\subsubsection{Multiple Emulsions}

Multiple emulsions are complex poly-dispersed systems that simultaneously contain both oil-in-water and water-in-oil emulsions [60]. Water-in-oil-in water $\left(\mathrm{W}_{1} / \mathrm{O} / \mathrm{W}_{2}\right)$ emulsion is the most common type of multiple emulsions, which comprises of small water droplets within larger oil droplets that are dispersed in an aqueous continuous phase (Figure 2b) $[1,61]$. Due to the presence of both water and oil compartments, multiple emulsions can simultaneously encapsulate and deliver hydrophilic and lipophilic bioactive compounds [1,62]. Both protein-polysaccharide complexes and Maillard-type conjugates have been applied to stabilize multiple emulsions, which have strong potential to function as bioactive ingredient delivery systems owing to their enhanced encapsulation efficiency, physical stability, protection and controlled release properties of loaded compounds [62-64]. Moreover, it was reported that pectin-whey protein complexes can be utilized as a desirable emulsifier with comparable properties as small molecule surfactants (Tween 80) for stabilizing $\mathrm{W}_{1} / \mathrm{O} / \mathrm{W}_{2}$ emulsions [65].

Table 2. Overview of protein-polysaccharide complex/conjugate-based delivery systems for bioactive ingredients.

\begin{tabular}{|c|c|c|c|c|}
\hline Types & Common Preparation Methods & Features & $\begin{array}{l}\text { Nature of Commonly } \\
\text { Encapsulated Compounds }\end{array}$ & References \\
\hline $\begin{array}{l}\text { Conventional } \\
\mathrm{O} / \mathrm{W} \text { emulsions }\end{array}$ & $\begin{array}{c}\text { High-energy methods (high-shear } \\
\text { mixers or } \\
\text { high-pressure homogenizers) }\end{array}$ & $\begin{array}{c}\text { Mean droplet radii }(0.2-100 \mu \mathrm{m}) \\
\text { thermodynamically } \\
\text { unstable systems }\end{array}$ & Lipophilic & [53-56] \\
\hline $\begin{array}{l}\text { Nanoemulsions } \\
\qquad(\mathrm{O} / \mathrm{W})\end{array}$ & $\begin{array}{l}\text { High-energy methods (high-speed } \\
\text { blenders, high-pressure } \\
\text { homogenizers, microfluidizers or } \\
\text { ultrasonic probes); Low-energy } \\
\text { methods (phase inversion and } \\
\text { solvent mixing approaches) }\end{array}$ & $\begin{array}{l}\text { Mean droplet radii }(50-200 \mathrm{~nm}) \\
\text { thermodynamically stable } \\
\text { isotropic systems }\end{array}$ & Lipophilic & {$[54,57-59]$} \\
\hline $\begin{array}{l}\text { Multiple emulsions } \\
\qquad\left(\mathrm{W}_{1} / \mathrm{O} / \mathrm{W}_{2}\right)\end{array}$ & $\begin{array}{c}\text { Producing primary } \mathrm{W} / \mathrm{O} \\
\text { emulsions before generating } \\
\mathrm{W}_{1} / \mathrm{O} / \mathrm{W}_{2} \text { emulsions }\end{array}$ & $\begin{array}{l}\text { Presence of both water and } \\
\text { oil compartments }\end{array}$ & Hydrophilic and lipophilic & [60-65] \\
\hline $\begin{array}{c}\text { Multilayered } \\
\text { emulsions }(\mathrm{O} / \mathrm{W})\end{array}$ & $\begin{array}{l}\text { Layer-by-layer }(\mathrm{LbL}) \text { electrostatic } \\
\text { deposition technique }\end{array}$ & $\begin{array}{l}\text { Stabilized by a multilayered } \\
\text { interfacial membrane; good } \\
\text { physical stability to } \\
\text { environmental stresses }\end{array}$ & Lipophilic & {$[54,66,67]$} \\
\hline $\begin{array}{c}\text { Pickering } \\
\text { emulsions }(\mathrm{O} / \mathrm{W})\end{array}$ & $\begin{array}{l}\text { High-energy methods } \\
\text { (Rotor-stator homogenization, } \\
\text { high-pressure } \\
\text { homogenization, sonication) }\end{array}$ & $\begin{array}{l}\text { Stabilized by solid particles; } \\
\text { long-term physical stability }\end{array}$ & Lipophilic & {$[54,68-70]$} \\
\hline Microcapsules & $\begin{array}{c}\text { Emulsion-spray drying; double } \\
\text { emulsion-complex } \\
\text { coacervation method }\end{array}$ & Containing a membrane shell & Lipophilic & {$[71-75]$} \\
\hline Hydrogels & $\begin{array}{l}\text { Complex coacervation and thermal } \\
\text { treatment to induce gelation }\end{array}$ & $\begin{array}{l}\text { Three-dimensional networks; } \\
\text { polymer crosslinking through } \\
\text { physical, ionic or covalent } \\
\text { interactions; including microgels } \\
\text { (d. } \mu \mathrm{m} \text { 1-350) and nanogels } \\
\text { (d. nm 20-250) }\end{array}$ & Hydrophilic & {$[76-82]$} \\
\hline $\begin{array}{c}\text { Core-shell } \\
\text { nanoparticles }\end{array}$ & $\begin{array}{l}\text { Coating protein nanoparticles } \\
\text { with polysaccharides }\end{array}$ & $\begin{array}{l}\text { Including protein inner core and } \\
\text { polysaccharide shell layer }\end{array}$ & Lipophilic & {$[1,83]$} \\
\hline $\begin{array}{l}\text { Composite } \\
\text { nanoparticles }\end{array}$ & $\begin{array}{l}\text { Anti-solvent precipitation; } \\
\text { emulsification-evaporation } \\
\text { method }\end{array}$ & $\begin{array}{l}\text { Formation of the } \\
\text { protein-polysaccharide } \\
\text { complexes prior to loading of } \\
\text { bioactive compounds }\end{array}$ & Lipophilic & {$[1,84,85]$} \\
\hline
\end{tabular}




\section{$\left\{\right.$ Polysaccharide Protein $\quad \begin{array}{l}\text { Hydrophobic } \\ \text { bioactive ingredient }\end{array}=\begin{array}{l}\text { Hydrophilic } \\ \text { bioactive ingredient }\end{array}$}

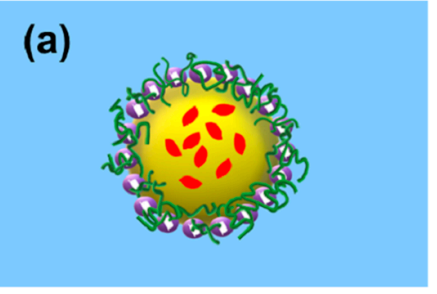

\section{Conventional emulsion/ Nanoemulsion (50-200 nm)}

(e)

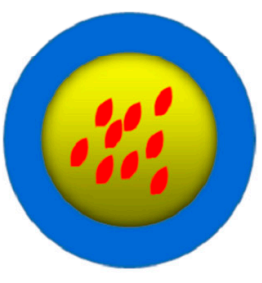

Microcapsule

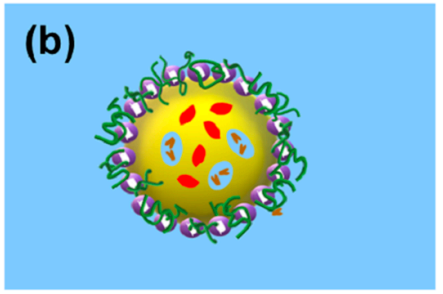

Multiple emulsion

(f)

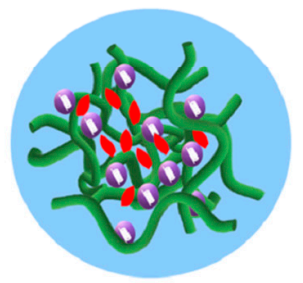

Hydrogel

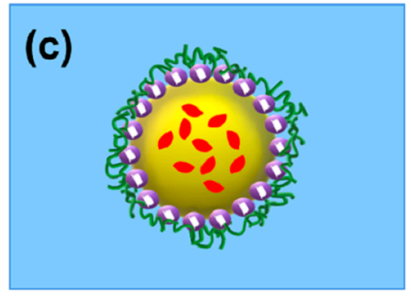

Multilayered emulsion

(g)

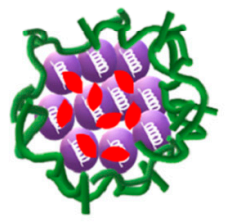

Core-shell nanoparticle

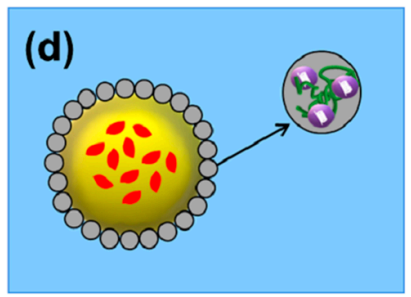

Pickering emulsion

(h)

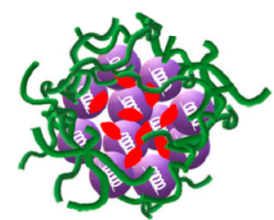

Composite nanoparticle

Figure 2. Different types of protein-polysaccharide complex/conjugate-based delivery systems for bioactive ingredients. (a) Conventional emulsion/Nanoemulsion (50-200 nm); (b) Multiple emulsion; (c) Multilayered emulsion; (d) Pickering emulsion; (e) Microcapsule; (f) Hydrogel; (g) Core-shell nanoparticle; (h) Composite nanoparticle.

\subsubsection{Multilayered Emulsions}

As shown in Figure 2c, multilayered emulsions are characterized as oil droplets electrostatically stabilized by a multilayered interfacial membrane. Generally, the interfacial membrane is composed of an emulsifier (e.g., proteins) and a charged biopolymer (e.g., polysaccharides) [66]. The multilayered emulsion structures are generated using the layerby-layer (LbL) electrostatic deposition technique [54]. For example, the multilayered $\mathrm{O} / \mathrm{W}$ emulsions stabilized by protein-polysaccharide complexes can be fabricated by direct adsorption of oppositely charged polysaccharides on a primary layer of proteins surrounding the oil droplet surface [66]. Multilayered emulsions have exhibited good physical stability to environmental stresses (e.g., ionic strength, $\mathrm{pH}$ and temperatures) and provided a promising delivery system for food bioactives $[66,67]$. For instance, multilayered emulsions formulated with $\beta$-lactoglobulin-pectin complex have been used for delivery purposes [67].

\subsubsection{Pickering Emulsions}

Pickering emulsions are stabilized by solid particles that are irreversibly adsorbed to the oil-water interface, as illustrated in Figure 2d [54]. Rotor-stator homogenization, high-pressure homogenization and sonication are the most commonly used techniques for preparing Pickering emulsions [68]. The solid particles function as a mechanical (steric) barrier that provide long-term physical stability of Pickering emulsions against coalescence and Ostwald ripening. In order to effectively stabilize the Pickering emulsions, the average size of particles at the interface needs to be at least 10-100 times smaller than that of emulsion droplets [54]. Protein-polysaccharide particles, such as xanthan gum-zein complex and ovotransferrin-gum arabic complex particles, have been recently applied as emulsifiers to fabricate food-grade Pickering emulsions with promising features as carriers for the protection and delivery of bioactive compounds [69,70]. 


\subsection{Microcapsule-Based Delivery Systems}

As depicted in Figure 2e, microcapsules consist of a membrane shell that creates a reservoir to encapsulate the core material [71]. Microcapsules are often designed for the protection and delivery of hydrophobic bioactive ingredients, such as oils and fat-soluble vitamins [1,72-74]. Moreover, microcapsules generated using double emulsion prior to the complex coacervation method have been used successfully to encapsulate hydrophilic compounds, such as anthocyanins, and improve their stability under harsh processing and storage conditions [75]. The shell materials of microcapsules have been devised using both Maillard-type protein-polysaccharide conjugates and electrostatic proteinpolysaccharide complexes [72,73]. For example, lycopene-loaded microcapsules have been constructed using Maillard-type whey protein isolate-xylo-oligosaccharide conjugates as the shell material [69]. In contrast, chia seed oil-loaded microcapsules were prepared by using chia seed protein-gum complexes as shell materials, leading to better release and digestive properties of the encapsulated oils compared to microcapsules derived from using individual protein or polysaccharide as shell materials [72].

\subsection{Hydrogel-Based Delivery Systems}

Hydrogels are three-dimensional networks that are formed by polymer cross-linking through physical, ionic, or covalent interactions, which can entrap large amounts of water (Figure 2f) [76,77]. The common method to prepare protein-polysaccharide hydrogels is complex coacervation and the subsequent thermal treatment to induce gelation [76]. The thermal process was reported to enhance the stability of hydrogels under different environmental stimuli and achieve sustained release of loaded food bioactives [78]. On the other hand, hydrogels can be produced by the assembly of Maillard-type protein-polysaccharide conjugates, which also possess good stability and dispersibility [9].

Based on particle size, hydrogels can be divided into microgels (d. $\mu \mathrm{m}$ 1-350) and nanogels (d. nm 20-250) [79]. Protein-polysaccharide-based nanogels are promising delivery vehicles for bioactive ingredients owing to their high loading capacity, controlled release property, improved bioaccessibility, good chemical stability, and smart responses to environmental stimuli [1]. Hydrogels are devised to mainly encapsulate hydrophilic compounds (e.g., folic acid and riboflavin) but they can also deliver hydrophobic bioactives (e.g., curcumin) [80-82].

\subsection{Nanoparticle-Based Delivery Systems}

Core-shell structure is one of the most common morphologies of protein-polysaccharide hybrid nanoparticles, as shown in Figure 2g. To produce core-shell nanoparticles, particles are first formed by creating protein nanoparticles as the inner core, followed by coating the protein core with hydrophilic polysaccharide as the shell structure [1]. Core-shell nanoparticles are often manufactured to encapsulate and deliver hydrophobic bioactive compounds (e.g., curcumin) due to the mostly hydrophobic interactions occurring with hydrophobic proteins such as zein $[1,83]$. Overall, the protein inner core provides good protection for the encapsulated compounds whereas the polysaccharide shell layer prevents particle aggregation and enhances stability by generating strong steric and electrostatic repulsions [1].

Composite nanoparticles are generated by formation of the protein-polysaccharide complexes prior to loading of bioactive compounds, as illustrated in Figure $2 \mathrm{~h}[1,84]$. It was demonstrated that hydrophobic interaction, electrostatic interaction, and hydrogen bonding played vital roles in the formation of zein-propylene glycol alginate composite nanoparticles. These composite nanoparticles functioned as a promising $\beta$-carotene delivery system by improving the physicochemical stability and controlled release of the hydrophobic compound [84]. Recently, Chen et al. reported that modification of zein-chitosan composite nanoparticles by atmospheric cold plasma treatment increased the encapsulation efficiency and dispersion stability of loaded resveratrol compared to untreated nanoparticles. The 
increased encapsulation efficiently was ascribed to the enhanced interaction between zein and chitosan after atmospheric cold plasma treatment [85].

\section{Applications of Protein-Polysaccharide Complexes/Conjugates as Delivery Systems for Food Bioactive Ingredients}

Food bioactive ingredients commonly loaded in the protein-polysaccharide-based delivery vehicles include polyphenols, proteins, bioactive peptides, carotenoids, vitamins, minerals, and essential oils [1]. The most widely investigated compounds were selected as representative bioactive ingredients, and major research findings on these compounds are summarized in Table 3 and illustrated in Figure 3. A recent review provided a detailed discussion on the microencapsulation of essential oils by the complex coacervation method using protein and polysaccharide [86]; thus, this topic is not reiterated in this section.

Table 3. Applications of protein-polysaccharide complexes/conjugates as delivery systems for representative food bioactive ingredients.

\begin{tabular}{|c|c|c|c|c|}
\hline $\begin{array}{l}\text { Bioactive } \\
\text { Ingredient }\end{array}$ & $\begin{array}{c}\text { Composition of } \\
\text { Delivery System }\end{array}$ & $\begin{array}{c}\text { Type of } \\
\text { Delivery System }\end{array}$ & $\begin{array}{c}\text { Improved Properties of } \\
\text { Encapsulated Bioactive Ingredient }\end{array}$ & References \\
\hline \multicolumn{5}{|c|}{ Polyphenols } \\
\hline Curcumin & Casein-soy polysaccharide & $\begin{array}{c}\text { Core-shell } \\
\text { nanoparticle }\end{array}$ & $\begin{array}{l}\text { Long-term dispersion stability; } \\
\text { oral bioavailability }\end{array}$ & [87] \\
\hline Curcumin & $\begin{array}{c}\text { Lysozyme- } A \text {. } \\
\text { Sphaerocephala Krasch } \\
\text { polysaccharide; } \\
\text { pea protein-carboxymethylated } \\
\text { corn fiber gum; pea protein } \\
\text { isolate-high } \\
\text { methoxyl pectin }\end{array}$ & $\begin{array}{l}\text { Core-shell } \\
\text { nanoparticle }\end{array}$ & $\begin{array}{l}\text { Chemical, thermal, and } \\
\text { photo stabilities }\end{array}$ & [88-90] \\
\hline Curcumin & Insect protein-chitosan & $\begin{array}{c}\text { Core-shell } \\
\text { nanoparticle }\end{array}$ & Release profile & [91] \\
\hline Curcumin & $\begin{array}{l}\text { Cationised gelatin-sodium } \\
\text { alginate; whey protein } \\
\text { nanofibril-gum arabic }\end{array}$ & $\begin{array}{l}\text { Core-shell } \\
\text { nanoparticle }\end{array}$ & $\begin{array}{l}\text { In vitro antioxidant and } \\
\text { anticancer activities }\end{array}$ & {$[92,93]$} \\
\hline Curcumin & $\begin{array}{l}\text { Whey protein } \\
\text { isolate-sodium alginate; } \\
\text { ovalbumin-k-carrageenan }\end{array}$ & $\begin{array}{l}\text { Composite } \\
\text { nanoparticle }\end{array}$ & $\begin{array}{l}\text { Dispersion, light and } \\
\text { chemical stabilities }\end{array}$ & [94-96] \\
\hline Curcumin & Zein-fucoidan & $\begin{array}{c}\text { Composite } \\
\text { nanoparticle }\end{array}$ & Sustained release & [97] \\
\hline Curcumin & Lactoferrin-pectin & $\begin{array}{l}\text { Composite } \\
\text { nanoparticle }\end{array}$ & In vitro antioxidant activities & [98] \\
\hline Curcumin & $\begin{array}{l}\text { Casein-soy soluble } \\
\text { polysaccharide }\end{array}$ & Nanoemulsion & $\begin{array}{l}\text { Storage stability; controlled release; } \\
\text { oral bioavailability }\end{array}$ & [99] \\
\hline Curcumin & $\begin{array}{l}\text { Bovine serum } \\
\text { albumin-dextran conjugate }\end{array}$ & Nanoemulsion & Chemical stability; oral bioavailability & [100] \\
\hline Curcumin & $\begin{array}{c}\text { Whey } \\
\text { protein-maltodextrin and } \\
\text { gum arabic }\end{array}$ & Microcapsule & Sustained release & [101] \\
\hline Curcumin & $\begin{array}{l}\beta \text {-lactoglobulin-propylene } \\
\text { glycol alginate }\end{array}$ & Hydrogel & $\begin{array}{l}\text { Sustained release; light and } \\
\text { storage stabilities }\end{array}$ & [102] \\
\hline Resveratrol & $\alpha$-lactalbumin-chitosan; & $\begin{array}{c}\text { Core-shell } \\
\text { nanoparticle }\end{array}$ & Light, heat and storage stabilities & [103] \\
\hline Resveratrol & $\begin{array}{l}\text { Zein-alginate/chitosan; } \\
\text { zein-chitosan }\end{array}$ & $\begin{array}{c}\text { Core-shell } \\
\text { nanoparticle }\end{array}$ & $\begin{array}{l}\text { Sustained release; bioaccessibility; } \\
\text { storage stability }\end{array}$ & {$[104,105]$} \\
\hline
\end{tabular}


Table 3. Cont.

\begin{tabular}{|c|c|c|c|c|}
\hline $\begin{array}{l}\text { Bioactive } \\
\text { Ingredient }\end{array}$ & $\begin{array}{c}\text { Composition of } \\
\text { Delivery System }\end{array}$ & $\begin{array}{c}\text { Type of } \\
\text { Delivery System }\end{array}$ & $\begin{array}{c}\text { Improved Properties of } \\
\text { Encapsulated Bioactive Ingredient }\end{array}$ & References \\
\hline Resveratrol & $\begin{array}{c}\text { Zein-pectin; } \\
\alpha \text {-lactalbumin-chitosan }\end{array}$ & $\begin{array}{c}\text { Core-shell } \\
\text { nanoparticle }\end{array}$ & $\begin{array}{l}\text { In vitro antioxidant and } \\
\text { anticancer activities }\end{array}$ & {$[103,106]$} \\
\hline Resveratrol & $\begin{array}{l}\text { Sodium } \\
\text { caseinate-corn starch } \\
\text { hydrolysate conjugate }\end{array}$ & $\mathrm{O} / \mathrm{W}$ emulsion & In vitro antioxidant activities & [107] \\
\hline Resveratrol & Lactoferrin-alginate & $\begin{array}{c}\text { Multilayered } \\
\text { emulsion }\end{array}$ & In vitro antioxidant activity & [108] \\
\hline \multicolumn{5}{|c|}{ Proteins and bioactive peptides } \\
\hline Lactoferrin & $\begin{array}{l}\text { Whey protein isolate-high } \\
\text { methoxyl pectin }\end{array}$ & Nanoparticle & Not determined & [109] \\
\hline $\begin{array}{c}\text { Casein } \\
\text { hydrolysate }\end{array}$ & $\begin{array}{l}\text { Soybean protein } \\
\text { isolate-pectin }\end{array}$ & Microcapsule & $\begin{array}{c}\text { Attenuated bitter taste; } \\
\text { decreased hygroscopicity }\end{array}$ & [110] \\
\hline Bioactive peptide & $\begin{array}{c}\text { Bioactive } \\
\text { peptide-pectin/chitosan }\end{array}$ & Double emulsion & Controlled release & [111] \\
\hline \multicolumn{5}{|c|}{ Carotenoids } \\
\hline Lutein & $\begin{array}{l}\text { Modified rice protein- } \\
\text { carboxymethylcellulose }\end{array}$ & $\begin{array}{c}\text { Core-shell } \\
\text { nanoparticle }\end{array}$ & $\begin{array}{l}\text { Controlled release; inhibited the } \\
\text { proliferation of breast cancer cells; } \\
\text { increased the lutein uptake rate } \\
\text { and absorption }\end{array}$ & [112] \\
\hline Lutein & $\begin{array}{l}\text { Zein-soluble soybean } \\
\text { polysaccharide }\end{array}$ & $\begin{array}{c}\text { Core-shell } \\
\text { nanoparticle }\end{array}$ & Bioaccessibility & [113] \\
\hline Lutein & $\begin{array}{l}\text { Whey protein } \\
\text { isolate-pectin }\end{array}$ & $\begin{array}{c}\text { Core-shell } \\
\text { nanoparticle }\end{array}$ & Storage stability & [114] \\
\hline Lutein & Casein-dextrin conjugate & $\mathrm{O} / \mathrm{W}$ emulsion & Dispersion stability & [115] \\
\hline Lutein & Egg yolk-modified starch & $\mathrm{O} / \mathrm{W}$ emulsion & $\begin{array}{l}\text { Physical and storage stabilities; low } \\
\text { lipid oxidation }\end{array}$ & [116] \\
\hline Lutein & $\beta$-lactoglobulin-gum arabic & Pickering emulsion & Storage stability & [117] \\
\hline$\beta$-Carotene & $\begin{array}{c}\text { Soy protein } \\
\text { isolate-Pleurotus eryngii } \\
\text { polysaccharide } \\
\text { conjugate; wheat } \\
\text { gluten-maltodextrin/citrus } \\
\text { pectin conjugate; } \\
\text { oat protein } \\
\text { isolate-Pleurotus ostreatus } \\
\beta \text {-glucan conjugate }\end{array}$ & $\mathrm{O} / \mathrm{W}$ emulsion & $\begin{array}{l}\text { Bioaccessibiliy; in vitro } \\
\text { antioxidant activity }\end{array}$ & [118-120] \\
\hline$\beta$-Carotene & $\begin{array}{l}\text { Whey protein } \\
\text { hydrolysate-pectin }\end{array}$ & Nanoemulsion & $\begin{array}{l}\text { Storage stability; in vitro } \\
\text { antioxidant activity }\end{array}$ & [121] \\
\hline$\beta$-Carotene & $\begin{array}{l}\text { Pea protein-high } \\
\text { methoxyl pectin }\end{array}$ & Pickering emulsion & pH stability & [122] \\
\hline Lycopene & Gelatin-pectin & Microcapsule & No desirable storage stability & [123] \\
\hline Lycopene & $\begin{array}{c}\text { Whey protein } \\
\text { isolate-xylo-oilgosaccharide } \\
\text { conjugate }\end{array}$ & Microcapsule & Storage stability; bioaccessibility & [73] \\
\hline \multicolumn{5}{|c|}{ Vitamins } \\
\hline Folic acid & $\begin{array}{l}\text { Soy protein-soy } \\
\text { polysaccharide }\end{array}$ & Nanogel & $\begin{array}{c}\text { Water dispersibility at acidic } \\
\text { conditions; chemical, light and } \\
\text { heat stabilities }\end{array}$ & [81] \\
\hline
\end{tabular}


Table 3. Cont.

\begin{tabular}{|c|c|c|c|c|}
\hline $\begin{array}{l}\text { Bioactive } \\
\text { Ingredient }\end{array}$ & $\begin{array}{c}\text { Composition of } \\
\text { Delivery System }\end{array}$ & $\begin{array}{c}\text { Type of } \\
\text { Delivery System }\end{array}$ & $\begin{array}{c}\text { Improved Properties of } \\
\text { Encapsulated Bioactive Ingredient }\end{array}$ & References \\
\hline Folic acid & $\begin{array}{c}\text { Whey } \\
\text { protein-maltodextrin }\end{array}$ & Double emulsion & Not determined & [124] \\
\hline Folic acid & Whey protein-pectin & Double emulsion & Sustained release & [125] \\
\hline Vitamin $\mathrm{D}_{3}$ & Ovalbumin-pectin & Microcapsule & Sustained release & [126] \\
\hline \multicolumn{5}{|c|}{ Mineral } \\
\hline Iron & $\begin{array}{l}\text { Whey protein } \\
\text { isolate-gellan gum }\end{array}$ & Hydrogel & $\begin{array}{l}\text { Burst release in simulated } \\
\text { gastric digestion }\end{array}$ & [127] \\
\hline Iron & $\begin{array}{c}\text { Whey protein } \\
\text { isolate-gum arabic }\end{array}$ & Nanoparticle & Sustained release & [128] \\
\hline
\end{tabular}

${ }^{1}$ Only protein-polysaccharide conjugates were identified, otherwise they were protein-polysaccharide complexes.

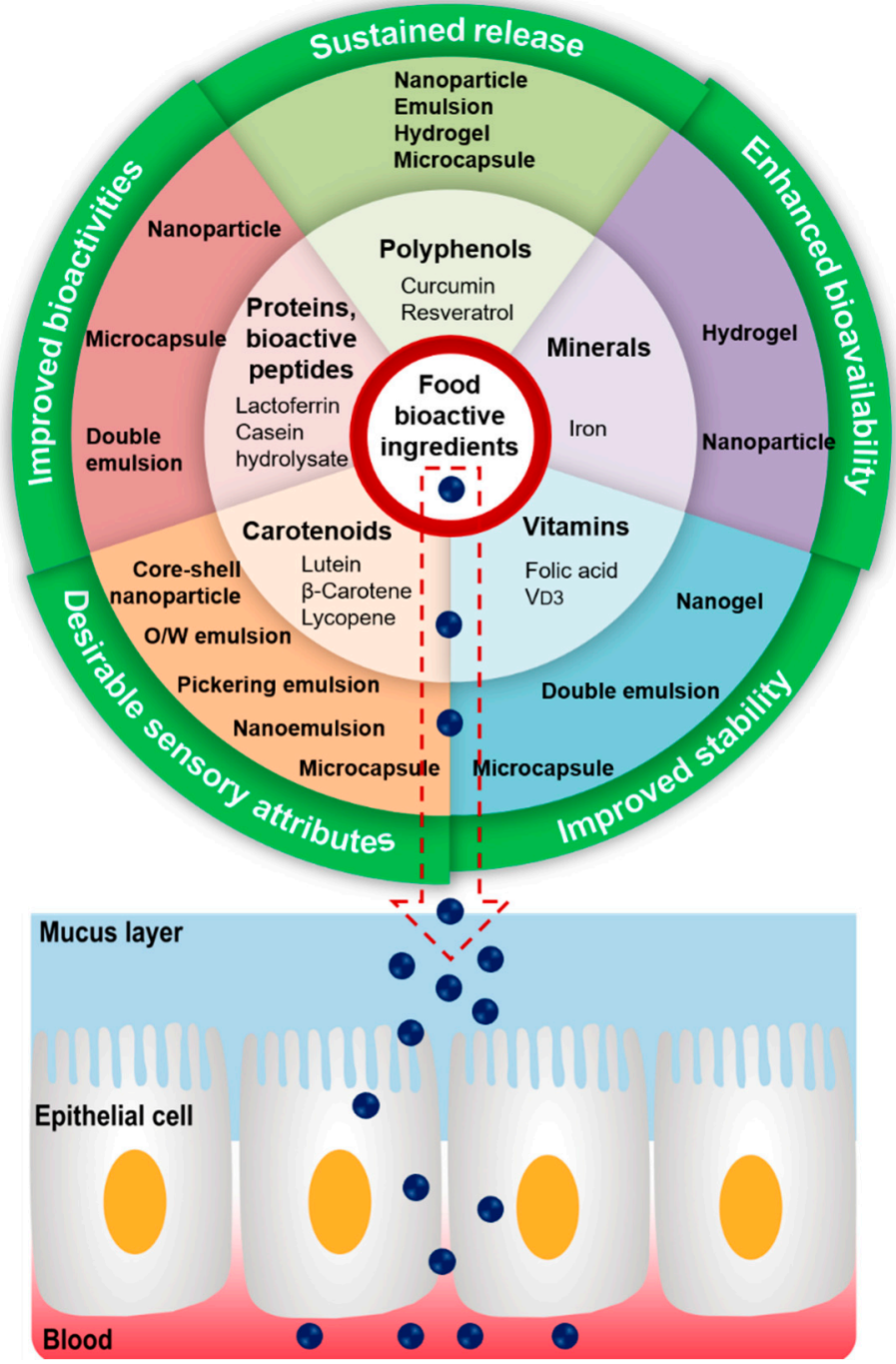

Figure 3. Summary of key points of discussion in Section 4. Considering the improved properties of loaded food bioactive ingredients, protein-polysaccharide-based delivery vehicles are promising approaches for enhancing cellular uptake and achieving systematic circulation. 


\subsection{Polyphenols}

Polyphenols have been simply classified into flavonoids and non-flavonoids [129]. A wide range of flavonoid-type polyphenolic compounds, such as anthocyanin [75,130], quercetin [131,132], isoquercetin [133], quercetagetin [134], epigallocatechin gallate [135], and curcumin [136], have been successfully encapsulated into different protein-polysaccharidebased carriers for protection, sustained release, and delivery.

Curcumin is often used as the model of hydrophobic bioactive compounds when designing and fabricating novel delivery systems. Hence, this review focused on only recent research progress on the protein-polysaccharide-based delivery systems for curcumin. Likewise, resveratrol was selected for discussion as the representative non-flavonoid polyphenol.

\subsubsection{Curcumin}

Curcumin, also called diferuloylmethane, is a natural polyphenolic compound present in the rhizome of Curcuma longa (turmeric) and in other Curcuma spp. [137]. Due to its wide range of health-promoting activities, such as antimutagenic, antimicrobial, antiinflammatory, and antioxidant activities, curcumin has strong potential to be applied as a functional food ingredient and nutraceutical [54]. However, curcumin has poor water solubility, low stability, and limited bioavailability, which restrict its application in the food industry. Substantial research efforts have been made to develop food-grade curcumin delivery vehicles in order to overcome the challenges and effectively deliver curcumin in targeted physiological sites [54]. Different types of curcumin delivery systems have been fabricated using protein-polysaccharide conjugates or complexes as building blocks, including core-shell nanoparticle, composite nanoparticle, microcapsule, emulsion, and hydrogel-based delivery systems.

In the past decade, a wide range of protein-polysaccharide complexes have been designed to fabricate core-shell nanoparticles for curcumin delivery, such as casein-soy polysaccharide [87], pea protein-carboxymethylated corn fiber gum [89], cationized gelatin and sodium alginate [92], insect protein-chitosan [91], native and succinylated pea proteinchitosan [138], whey protein-gum arabic [93], and soybean protein isolate-fucoidan complexes [136]. Encapsulation efficiencies of curcumin in these developed core-shell nanoparticles ranged from 30-99\% [89,91,93]. The curcumin-loaded casein-soy polysaccharide nanoparticles showed long-term dispersion stability after 30 days of storage at $25^{\circ} \mathrm{C}$ [87]. Likewise, the chemical, thermal, and photo stabilities of encapsulated curcumin have been significantly improved. Specifically, lysozyme-A. Sphaerocephala Krasch polysaccharide complex nanoparticles increased curcumin stability at physiological $\mathrm{pH}$ in aqueous buffer [88]. Approximate $75 \%$ of free curcumin degraded in phosphate buffer within $6 \mathrm{~min}$, while $59 \%$ and $46 \%$ of encapsulated curcumin remained stable after $24 \mathrm{~h}$ and $48 \mathrm{~h}$ incubation, respectively [88]. Compared to free curcumin (15\%), curcumin-loaded pea protein-carboxymethylated corn fiber gum nanoparticles showed a significantly higher thermal stability (95\%) after heat treatment $\left(80^{\circ} \mathrm{C}, 30 \mathrm{~min}, \mathrm{pH} 3.5\right)$ [89]. Regarding photo stability, it was reported that after $90 \mathrm{~min}$ of UV radiation, the residual levels of curcumin in the free and nanoencapsulated forms (pea protein isolate-high methoxyl pectin complexes) were $4 \%$ and $34 \%$, respectively [ 90 ]. In addition, the release profile and oral bioavailability of encapsulated curcumin are of great significance for achieving its health-promoting activities. The release kinetics of curcumin from insect protein-chitosan nanoparticles were determined under the simulated oral, gastric, and intestinal conditions [91]. More than $90 \%$ of encapsulated curcumin was released after the simulated digestion process, including $6.3 \%$ in oral phase, $8.2 \%$ in gastric phase, and $78.1 \%$ in intestinal phase. A recent study demonstrated that the oral bioavailability of curcumin loaded in casein-soy polysaccharide complexes increased 3.4-fold in blood of mice compared to the curcumin/Tween 20 treatment [87]. Furthermore, encapsulated curcumin in core-shell nanoparticles showed better antioxidant and anticancer activities in vitro compared to free curcumin $[88,89,92,93]$.

Likewise, encapsulation of curcumin in protein-polysaccharide composite nanoparticles has gained significant research attention. The possible encapsulation mechanism of 
these nanoparticles is that the formation of protein-polysaccharide complexes results in protein unfolding and exposure of the hydrophobic pockets, which facilitate curcumin binding to the protein moiety of complexes via hydrophobic interactions [94]. Encapsulation efficiencies of curcumin in composite nanoparticles are usually higher than $80 \%[97,139]$. Moreover, curcumin-encapsulated composite nanoparticles have shown great potential in food applications owing to their high dispersion stability and color stability [140]. For example, curcumin-loaded composite nanoparticles (whey protein isolate-sodium alginate nanocomplex) possessed acceptable dispersion stability (no obvious precipitates) in model food processing and storage conditions, such as high concentrations of sucrose and $\mathrm{NaCl}$, and heat treatment at $90^{\circ} \mathrm{C}$ for $2 \mathrm{~h}$ [95]. Composite nanoparticles effectively provided curcumin protection against light and different $\mathrm{pH}$ [94-96]. A sustained release of curcumin from composite nanoparticles has been observed in simulated gastric and intestinal fluids, which led to enhanced bioaccessibility of curcumin [96]. Taking the curcumin-loaded zein-fucoidan nanoparticle as an example, the cumulative release rates of curcumin were $10 \%$ and $62 \%$ in simulated gastric fluid $(90 \mathrm{~min})$ and simulated intestinal fluid (240 $\mathrm{min})$, respectively [97]. Many studies have demonstrated that the in vitro antioxidant activities of curcumin in composite nanoparticles were remarkably improved [95,98].

Besides nanoparticle-based delivery systems, curcumin has been successfully loaded in other types of protein-polysaccharide delivery vehicles, such as oil-in-water emulsions [99,100], microcapsules [101], and hydrogels [102]. Specifically, the curcumin loading efficiency of nanoemulsion stabilized by casein-soy soluble polysaccharide complexes was as high as $99.9 \%$ and only $3 \%$ of the loaded curcumin degraded during storage at $4{ }^{\circ} \mathrm{C}$ for 40 days [99]. A controlled release of curcumin from the nanoemulsion was achieved during simulated gastrointestinal digestion and an 11-fold increase in curcumin oral bioavailability in mice was observed [99]. Likewise, nanoemulsion with Maillard-type bovine serum albumin-dextran conjugates was fabricated for protection and oral delivery of curcumin [100]. When curcumin was encapsulated in spray-dried microcapsules fabricated with whey protein-maltodextrin and gum arabic, it became resistant to in vitro gastric digestion but was released in simulated intestinal fluids [101]. Recently, Su et al [102]. developed a $\beta$-lactoglobulin-propylene glycol alginate-based hydrogel for co-delivery of curcumin and probiotics. Besides protection of probiotics, the encapsulated curcumin had a sustained release in simulated gastrointestinal tract conditions and exhibited good stability when exposed to light and during long-term storage [102].

\subsubsection{Resveratrol}

Resveratrol is a non-flavonoid polyphenol with numerous health promoting properties, such as antioxidant, anti-inflammatory, anti-proliferative, anticancer, and anti-aging activities [106]. Nonetheless, utilization of resveratrol as a nutraceutical or functional food ingredient is challenged by its poor water solubility, chemical instability, and low bioavailability [106]. To address these issues, distinct types of protein-polysaccharide-based delivery systems, such as core-shell nanoparticles, oil-in-water emulsions, and multilayered emulsions, have been developed [104,108,141].

When resveratrol was loaded into core-shell nanoparticles, the encapsulation efficiencies often ranged from $50 \%$ to $90 \%$ [105,142]. It was reported that $28 / 40$ dual-frequency ultrasound effectively increased the encapsulation efficiency of resveratrol in zein-chitosan complex nanoparticles from $51 \%$ to $65 \%$ [142]. After encapsulation, resveratrol lost its crystalline structure and changed to the amorphous form in alginate/chitosan-zein nanoparticles and $\alpha$-lactalbumin-chitosan nanoparticles $[103,104]$. The major driving forces between resveratrol and $\alpha$-lactalbumin-chitosan nanoparticles include hydrophobic interaction and hydrogen bonding [103]. Light, heat, and storage stabilities of encapsulated resveratrol in core-shell nanoparticles were remarkably increased compared to those of free resveratrol. For example, after exposure to UV light for $200 \mathrm{~min}$ and heat treatment at $85^{\circ} \mathrm{C}$ for $300 \mathrm{~min}$, the retention rates of free and encapsulated resveratrol in $\alpha$-lactalbumin-chitosan nanoparticles were $44 \%$ and $47 \%$, and $85 \%$ and $86 \%$, respectively [103]. Moreover, sustained in vitro 
release of resveratrol from nanoparticles in simulated gastrointestinal digestion could be enhanced. For instance, in simulated gastric phase, $77 \%$ of free resveratrol was released compared to 52\% released from resveratrol encapsulated in zein nanoparticles [104]. A recent study evidently demonstrated that compared to free resveratrol, the in vitro bioaccessibility of encapsulated resveratrol in hollow zein-chitosan nanoparticles increased 2-fold from $44 \%$ to $90 \%$ [105]. Consequently, in vitro antioxidant and anticancer activities of the encapsulated resveratrol were improved as well $[103,106]$. However, there is a dearth of information on the oral bioavailability and in vivo bioactivities of encapsulated resveratrol.

It has been reported that when loading a low amount of resveratrol $(0.02 \mathrm{~g} / 100 \mathrm{~g})$ into the oil-in-water emulsion stabilized by Maillard-type sodium caseinate-corn starch hydrolysate conjugates, the in vitro antioxidant activity significantly increased [107]. Foodgrade protein-polysaccharide multilayered emulsions have also been designed to encapsulate and protect resveratrol and to increase its antioxidant activity [108]. Lactoferrinalginate multilayered emulsions were reported to be stable only at a high concentration of alginate $(>0.18 \% w / w)$ owing to the bridging flocculation effect at low alginate concentrations [108]. The antioxidant activity of this resveratrol-loaded multilayered emulsions was maintained during storage for 4 weeks whereas decreased antioxidant activity of free resveratrol was observed in the third week [108].

\subsection{Proteins and Bioactive Peptides}

Beyond their nutritional properties, several food proteins and peptides have demonstrated numerous health-promoting properties, such as antihypertensive, antimicrobial, cholesterol-lowering, antithrombotic, anticancer, immunomodulatory, mineral binding, opioid-like, and antioxidant activities [143]. However, the in vitro biological activities of proteins and bioactive peptides do not generally translate into in vivo pharmacological functions in animal studies and human clinical trials [2]. One of the major reasons for this discrepancy is the low biostability or bioaccessibility of proteins and peptides during gastrointestinal digestion, which further results in low bioavailability $[144,145]$. In addition, bioactive peptides often have a bitter taste and hygroscopicity due to the exposure of hydrophobic and hygroscopic amino acid residues resulting from hydrolysis, which limit their applications in food product development [2]. Protein-polysaccharide-based delivery systems have been developed for protection and controlled release of proteins and bioactive peptides in order to enhance their in vivo bioactivities, and sensory and physicochemical properties. For example, lactoferrin has been trapped in nanocarriers for broadening its applications in food and pharmaceutical industries [109]. The highest encapsulation efficiency of lactoferrin in whey protein isolate-high methoxyl pectin nanoparticles was reported at the optimum condition of 2:1 protein-pectin ratio $(w / w)$ and pre-acidification at $\mathrm{pH}$ 3.5. However, encapsulation efficiency was only $25 \%$ at the optimized conditions [109]. In addition to enhancing the encapsulation efficiency, the release profile, stability, and biological activities of encapsulated lactoferrin need to be explored in future studies.

Furthermore, a soybean protein isolate-pectin microcapsule has been designed to encapsulate casein hydrolysates for attenuating the bitter taste and hygroscopicity [110]. The encapsulation efficiency decreased from $92 \%$ to $79 \%$ when the loading amount of casein hydrolysate increased from $50 \%$ to $150 \%(w / w)$. The results showed that encapsulated hydrolysates had lower hygroscopicity and less bitter taste compared to free hydrolysate [110]. Jo and Schaaf [111] recently fabricated food-grade double emulsions $\left(\mathrm{W}_{1} / \mathrm{O} / \mathrm{W}_{2}\right)$ to improve the controlled release of bioactive peptides at different temperatures. The bioactive peptide-polysaccharide complex-loaded double emulsions had encapsulation efficiency of $>90 \%$ and possessed a higher heat stability. Controlled release of encapsulated bioactive peptide from the double emulsions was observed at $45^{\circ} \mathrm{C}(<1 \%)$ and $65^{\circ} \mathrm{C}(<30 \%)$ during storage for $4 \mathrm{~h}$. Oil types played notable roles in the peptide release from the double emulsions. More rapid release of the peptide was observed for double emulsions containing oil with medium chain triglycerides, e.g., coconut oil, compared to oil with long chain triglycerides, e.g., canola oil [111]. 


\subsection{Carotenoids}

Carotenoids are natural pigments in various fruits and vegetables, which have many human health benefits, such as antioxidant, intercellular communication, and immune system activities. Carotenoids can be classified into two groups on the basis of their chemical structures, including xanthophylls (e.g., lutein) and carotenes (e.g., $\beta$-carotene and lycopene) [146]. It is challenging to utilize carotenoids as natural colorants in food products due to their low water solubility and chemical instability. Encapsulation in protein-polysaccharide systems is a suitable approach to overcome this barrier.

\subsubsection{Lutein}

Core-shell nanoparticle-based carriers are widely investigated for encapsulation and oral delivery of lutein [112]. For example, compared to lutein-loaded protein nanoparticles, modified rice protein-carboxymethylcellulose nanoparticles efficiently controlled the release of lutein during gastrointestinal digestion, effectively inhibited the proliferation of breast cancer cells, and increased the lutein uptake rate and absorption [112]. Nonetheless, proteins also play essential roles in the formation of core-shell nanoparticles for lutein delivery. It was suggested that a high mass ratio of protein-lutein increased encapsulation efficiency. The encapsulation efficiency of lutein in zein-soluble soybean polysaccharide nanoparticles was higher than $80 \%$ when the mass ratio of zein-lutein was 25:1. However, encapsulation efficiency was only $35 \%$ at the mass ratio of 10:1 [113]. Bioaccessibility of the encapsulated lutein was two times higher than that of free lutein [113]. To increase the stability of lutein carriers, the formation parameters of whey protein isolate-pectin nanoparticles (protein-polysaccharide ratio, $\mathrm{pH}$, and type of pectin) have been optimized. The most stable system was established with low methoxyl pectin at a protein-polysaccharide ratio of 4:1 and $\mathrm{pH} 5.0$; the carrier remained stable after storage for 30 days [114].

Oil-in-water emulsions are another common type of lutein delivery system with good stability, which can be emulsified by both Maillard-type protein-polysaccharide conjugates and electrostatic complexes $[115,116]$. Specifically, lutein-loaded emulsions stabilized by casein-dextrin conjugates were reported to be stable at a wide range of $\mathrm{pH}$ values (from 3 to 7) and not aggregate during simulated gastric digestion; this was attributed to the steric repulsion resulting from the dextran [115]. Moreover, lutein-enriched emulsions stabilized by egg yolk-modified starch complexes, especially egg yolk-hydroxypropyl distarch phosphate complexes, showed good physical stability, low lipid oxidation, and high lutein retention during storage at $37^{\circ} \mathrm{C}$ [116].

Lutein has also been encapsulated in Pickering emulsions stabilized by $\beta$-lactoglobulin-gum arabic-based nanoparticles. The nanoparticles exhibited a core-shell structure and significantly contributed to the stability of the Pickering emulsions. The formed emulsions showed a high resistance against flocculation and coalescence and favorable storage stability. After 12 weeks of storage, more than $90 \%$ of encapsulated lutein was retained in the Pickering emulsions [117].

\subsection{2. $\beta$-Carotene}

Due to the antioxidant and pro-vitamin A nature of $\beta$-carotene, many attempts have been made to develop delivery systems to enhance its dispersant state, chemical stability, bioavailability, and functionalities. By and large, $\mathrm{O} / \mathrm{W}$ emulsions are effective for the protection and delivery of $\beta$-carotene $[118,147]$. $\mathrm{O} / \mathrm{W}$ emulsion-based $\beta$-carotene delivery systems are commonly stabilized by Maillard-type protein-polysaccharide conjugates [118-120,147]. The increased emulsifying activity of protein-polysaccharide (e.g., soy protein isolate-Pleurotus eryngii polysaccharide) conjugates was attributed to their decreased surface hydrophobicity and flat surface morphology [119]. A recent study demonstrated that ovalbumin-dextran conjugates possessed good emulsifying stability in different environmental conditions, including $\mathrm{pH}$ (3.0-10.0), high ionic strength $(150 \mathrm{mM} \mathrm{NaCl})$, and thermal treatment $\left(90^{\circ} \mathrm{C}\right.$ for $\left.30 \mathrm{~min}\right)$ [147]. Bioaccessibility of encapsulated $\beta$-carotene in $\mathrm{O} / \mathrm{W}$ emulsions stabilized by deamidated wheat gluten-maltodextrin conjugates was close to $60 \%$ [118]. The enhanced bioaccessibility favorably contributed to the increased antioxidant activity of $\beta$-carotene in Caco-2 intestinal cells $[119,120]$. 
$\beta$-carotene has been successfully entrapped in $\mathrm{O} / \mathrm{W}$ nanoemulsions stabilized by whey protein hydrolysate-pectin soluble complexes and the concentration of $\beta$-carotene was considered as a critical parameter [121]. Average droplet size of the nanoemulsion was $~ 95$ $\mathrm{nm}$, and encapsulation efficiency was as high as $92 \%$ when the concentration of $\beta$-carotene was $25 \mathrm{mg} / 100 \mathrm{~g}$ emulsion. However, when the concentration of $\beta$-carotene increased to $75 \mathrm{mg} / 100 \mathrm{~g}$ emulsion, the nanoemulsion displayed a larger droplet size $(127 \mathrm{~nm})$ and a significantly lower encapsulation efficiency (27\%). Additionally, lower concentration of loaded $\beta$-carotene increased nanoemulsion stability against droplet coalescence and retarded the loss of antioxidant activity of $\beta$-carotene during storage [121]. Moreover, Yi et al. [122] designed high-internal phase Pickering emulsions stabilized by pea proteinhigh methoxyl pectin colloidal particles as novel $\beta$-carotene delivery systems. The spherical protein-polysaccharide colloidal particles were formed spontaneously by electrostatic interaction. The fabricated $\beta$-carotene-loaded Pickering emulsions displayed high stability against $\mathrm{pH}$ variation. However, bioaccessibility of the encapsulated $\beta$-carotene in Pickering emulsions was only $26 \%$ [122], which needs to be improved if intended to be used in practical food applications.

\subsubsection{Lycopene}

Due to its highly unsaturated structure, lycopene is sensitive to heat and light, which may result in oxidation and isomerization [123]. Protein-polysaccharide-based microcapsules have been fabricated to encapsulate lycopene [123]. When gelatin-pectin complexes were utilized as the wall materials, encapsulation efficiency of lycopene was higher than $90 \%$. However, this microcapsule-based delivery system did not provide effective protection for lycopene during storage, with degradation rate of $14 \%$ per week [123]. When Maillard-type whey protein isolate-xylo-oilgosaccharide conjugates were applied as wall materials, storage stability of the encapsulated lycopene was improved. The degradation rates of lycopene after storage for 36 days at 4,25 , and $40{ }^{\circ} \mathrm{C}$ were $12 \%, 54 \%$, and $60 \%$, respectively. Meanwhile, the microcapsules based on protein-polysaccharide conjugates resulted in high encapsulation efficiency $(94 \%)$ and lycopene solubility $(92 \mathrm{~g} / \mathrm{L})$. Compared to free lycopene, bioaccessibility of the encapsulated lycopene significantly increased from $16 \%$ to $60 \%$. Hence, whey protein isolate-xylo-oilgosaccharide conjugate-based microcapsules are considered as promising lycopene delivery systems [73].

\subsection{Vitamins}

Vitamins are defined as a group of essential micronutrients that cannot be synthesized by the human body; they are classified into fat-soluble (A, D, E, and K) and water-soluble vitamins (e.g., folic acid) [148]. Deficiency of vitamins can result in severe diseases, such as scurvy and night blindness [148]. Vitamins can easily be degraded during food processing and storage since they are chemically reactive and sensitive to environmental factors such as light, $\mathrm{pH}$, temperature, and oxygen [148]. It is well established that microencapsulation and nanoencapsulation prevent vitamin loss during food processing and storage, and help to achieve targeted delivery and sustained release [148,149]. However, limited research has been conducted to date on development of protein-polysaccharide-based vitamin delivery systems. Most existing research has particularly focused on folic acid and vitamin $\mathrm{D}_{3}$ delivery.

To improve the stability and controlled delivery of folic acid, soy protein-soy polysaccharide complex nanogels were developed [81]. The folic acid-loaded nanogels possessed good water dispersibility in acidic conditions due to the presence of a polysaccharide surface. More importantly, the nanogels provided strong protection of folic acid from heat, oxygen, and light in acidic conditions, whereas the encapsulated folic acid showed a rapid release at neutral $\mathrm{pH}$ value [81]. Another study prepared and optimized stable $\mathrm{W}_{1} / \mathrm{O} / \mathrm{W}_{2}$ whey protein-maltodextrin double emulsions for folic acid encapsulation by the low-energy emulsification technique [124]. The folic acid-encapsulated nanoemulsions showed potential for utilization in fortification of liquid foods but limited applications in 
solid foods [124]. To address this drawback, a spray drying technique was used to prepare folic acid-incorporated whey protein-pectin nanoparticles, which led to the lowest release rate of folic acid at $\mathrm{pH} 4$ and highest release at $\mathrm{pH} 11$ [125].

Vitamin $\mathrm{D}_{3}$ is a lipid-soluble compound that easily degrades under acidic conditions. Ovalbumin-pectin nanocomplexes were developed as effective carriers for vitamin $\mathrm{D}_{3}$ with encapsulation efficiency of $96 \%$. Encapsulation of vitamin $\mathrm{D}_{3}$ in the nanocomplexes was driven by electrostatic interactions, hydrogen bonding, and hydrophobic interactions. In vitro release study indicated that only $11 \%$ of loaded vitamin $\mathrm{D}_{3}$ was released from the nanocomplexes in simulated gastric fluid within $60 \mathrm{~min}$, whereas in simulated intestinal fluid, the cumulative release rate within 120 min reached 98\% [126]. Furthermore, it was demonstrated that the addition of sodium alginate significantly enhanced the stability of vitamin $\mathrm{D}_{3}$-incorporated ovalbumin-pectin nanocomplexes due to the strong negative charge of sodium alginate [150].

\subsection{Mineral (Iron)}

Some minerals, such as iron, calcium, and zinc, play important biological roles and are essential micronutrients for maintaining human health. Hence, food fortification with minerals has been considered as one of the most effective strategies for combating micronutrient malnutrition globally. However, mineral fortification can adversely influence the physical and sensory properties of foods, and the absorption and bioavailability of fortified minerals could be impeded by other food components such as phytates [151]. To overcome these challenges, research efforts have led to the development of effective protein-polysaccharide-based carriers for protection and delivery of minerals, especially iron [127,128]. Kazemi-Taskooh and Varidi [127] designed a composite cold-set hydrogel formulated with whey protein isolate and gellan gum as an iron delivery system. The encapsulation efficiency of iron in hydrogel reached $94 \%$, and was affected by total biopolymer concentration, protein/polysaccharide ratio, and iron concentration. However, a majority of the encapsulated iron (up to $89 \%$ ) was released from the hydrogel in simulated gastric digestion rather than simulated intestinal digestion. This could be because of the cationic net charge of proteins at low acidic $\mathrm{pH}$, resulting in electrostatic repulsion and dissociation of bound iron from the complex. Increase gastric stability and sustained release of iron in the intestinal phase need to be enhanced by modification of the hydrogel structures. On the other hand, nanoparticle-based iron delivery systems, which were fabricated with whey protein isolate and gum arabic, dramatically slowed the release of entrapped iron (only $20 \%$ released) in the simulated gastric phase [128].

\section{Conclusions and Future Perspectives}

Protein-polysaccharide complexes and conjugate-based carriers have shown tremendous promise for encapsulation, protection, and delivery of food bioactive ingredients. The loaded food bioactive ingredients exhibited enhanced physicochemical stability, bioaccessibility, and sustained release in simulated gastrointestinal conditions. However, it is still challenging to achieve the optimum delivery for specific bioactive ingredients, for example, simultaneously optimizing all parameters such as physicochemical stability, loading amount, controlled release, good protection, bioaccessibility, and bioavailability. Considering the different characteristics of specific bioactive ingredients, the overall performance of the delivery systems could be improved by selection of suitable proteins and polysaccharides, and control of operation parameters of formation of protein-polysaccharide conjugates and complexes.

Currently, most studies have applied an in vitro simulated gastrointestinal digestion model that consists of digestive juices and enzymes to evaluate the release profile and bioaccessibility of encapsulated bioactive ingredients, without taking into account the role of gut microbiota. An in vitro simulator of the human intestinal microbial ecosystem (SHIME) is a potential model to address this challenge. More importantly, mucus can be incorporated into the SHIME model, which can be utilized to investigate the impact of the 
mucus layer on cellular uptake and transport mechanisms of bioactive-loaded delivery systems. Besides in vitro studies, more research needs to be conducted in understanding the effect of protein-polysaccharide-based delivery systems on in vivo oral bioavailability of encapsulated bioactive compounds. Moreover, current research has mainly focused on the application of the protein-polysaccharide-based delivery systems to polyphenols, particularly curcumin. Future research needs to focus on the design and fabrication of efficient protein-polysaccharide-based delivery vehicles for vitamins and minerals.

Author Contributions: Conceptualization, supervision, investigation, formal analysis, validation, visualization, writing — original draft, review and editing, funding acquisition, X.S.; investigation, validation, visualization, H.W.; investigation, validation, visualization, S.L.; investigation, visualization, funding acquisition, C.S.; investigation, visualization, S.Z.; funding acquisition, writing-review and editing, J.R.; conceptualization, validation, writing-review and editing, C.C.U. All authors have read and agreed to the published version of the manuscript.

Funding: X. Sun was supported by a research grant from the Research Center of Corn Staple Food of Heilongjiang Province of China (Grant number: SPKF202020). J. Ren. and C. Song. received grants from major special project of Heilongjiang province (Grant number: 2021ZX12B09 \& 2019ZX06B02) and basic scientific research business expenses of provincial colleges and universities in Heilongjiang Province (Grant number: YSTSXK201804).

Institutional Review Board Statement: Not applicable.

Informed Consent Statement: Not applicable.

Acknowledgments: X. Sun would like to thank the NSERC Postdoctoral Fellowship and Postdoctoral Fellowships in Nutrition and Mental Health (University of Ottawa).

Conflicts of Interest: The authors declare no conflict of interest.

\section{References}

1. Wei, Z.; Huang, Q. Assembly of protein-polysaccharide complexes for delivery of bioactive ingredients: A perspective paper. J. Agric. Food Chem. 2019, 67, 1344-1352. [CrossRef] [PubMed]

2. Mohan, A.; Rajendran, S.R.; He, Q.S.; Bazinet, L.; Udenigwe, C.C. Encapsulation of food protein hydrolysates and peptides: A review. Rsc Adv. 2015, 5, 79270-79278. [CrossRef]

3. Ru, Q.; Wang, Y.; Lee, J.; Ding, Y.; Huang, Q. Turbidity and rheological properties of bovine serum albumin/pectin coacervates: Effect of salt concentration and initial protein/polysaccharide ratio. Carbohyd. Polym. 2012, 88, 838-846. [CrossRef]

4. de Oliveira, F.C.; Coimbra, J.S.d.R.; de Oliveira, E.B.; Zuñiga, A.D.G.; Rojas, E.E.G. Food protein-polysaccharide conjugates obtained via the Maillard reaction: A review. Crit. Rev. Food Sci. Nutr. 2016, 56, 1108-1125. [CrossRef]

5. Naik, R.R.; Wang, Y.; Selomulya, C. Improvements of plant protein functionalities by Maillard conjugation and Maillard reaction products. Crit. Rev. Food Sci. Nutr. 2021, 1-26. [CrossRef]

6. Zhang, Q.; Zhou, Y.; Yue, W.; Qin, W.; Dong, H.; Vasanthan, T. Nanostructures of protein-polysaccharide complexes or conjugates for encapsulation of bioactive compounds. Trends Food Sci. Technol. 2021, 109, 169-196. [CrossRef]

7. Maillard, L. Action of amino acids on sugars. Formation of melanoidins in a methodical way. Compte-Rendu L'acad. Sci. 1912, 154, 66-68.

8. Akhtar, M.; Ding, R. Covalently cross-linked proteins \& polysaccharides: Formation, characterisation and potential applications. Curr. Opin. Colloid Interface Sci. 2017, 28, 31-36. [CrossRef]

9. Nooshkam, M.; Varidi, M. Maillard conjugate-based delivery systems for the encapsulation, protection, and controlled release of nutraceuticals and food bioactive ingredients: A review. Food Hydrocoll. 2020, 100, 105389. [CrossRef]

10. Silván, J.M.; Assar, S.H.; Srey, C.; Del Castillo, M.D.; Ames, J.M. Control of the Maillard reaction by ferulic acid. Food Chem. 2011, 128, 208-213. [CrossRef]

11. Zhu, D.; Damodaran, S.; Lucey, J.A. Physicochemical and emulsifying properties of whey protein isolate (WPI)-Dextran conjugates produced in aqueous solution. J. Agric. Food Chem. 2010, 58, 2988-2994. [CrossRef]

12. He, W.; Tian, L.; Zhang, S.; Pan, S. A novel method to prepare protein-polysaccharide conjugates with high grafting and low browning: Application in encapsulating curcumin. LWT 2021, 145, 111349. [CrossRef]

13. Usui, M.; Tamura, H.; Nakamura, K.; Ogawa, T.; Muroshita, M.; Azakami, H.; Kanuma, S.; Kato, A. Enhanced bactericidal action and masking of allergen structure of soy protein by attachment of chitosan through Maillard-type protein-polysaccharide conjugation. Nahrung 2004, 48, 69-72. [CrossRef] [PubMed]

14. Nakamura, S.; Ogawa, M.; Nakai, S.; Kato, A.; Kitts, D.D. Antioxidant activity of a Maillard-type Phosvitin-Galactomannan conjugate with emulsifying properties and heat stability. J. Agric. Food Chem. 1998, 46, 3958-3963. [CrossRef] 
15. Gentile, L. Protein-polysaccharide interactions and aggregates in food formulations. Curr. Opin. Colloid Interface Sci. 2020, 48, 18-27. [CrossRef]

16. Kato, A.; Minaki, K.; Kobayashi, K. Improvement of emulsifying properties of egg white proteins by the attachment of polysaccharide through Maillard reaction in a dry state. J. Agric. Food Chem. 1993, 41, 540-543. [CrossRef]

17. Bi, B.; Yang, H.; Fang, Y.; Nishinari, K.; Phillips, G.O. Characterization and emulsifying properties of $\beta$-lactoglobulin-gum Acacia Seyal conjugates prepared via the Maillard reaction. Food Chem. 2017, 214, 614-621. [CrossRef]

18. Ledesma-Osuna, A.I.; Ramos-Clamont, G.; Guzman-Partida, A.M.; Vazquez-Moreno, L. Conjugates of bovine serum albumin with chitin oligosaccharides prepared through the Maillard reaction. J. Agric. Food Chem. 2010, 58, 12000-12005. [CrossRef]

19. Sheng, L.; Su, P.; Han, K.; Chen, J.; Cao, A.; Zhang, Z.; Jin, Y.; Ma, M. Synthesis and structural characterization of lysozymepullulan conjugates obtained by the Maillard reaction. Food Hydrocoll. 2017, 71, 1-7. [CrossRef]

20. Guan, Y.-G.; Lin, H.; Han, Z.; Wang, J.; Yu, S.-J.; Zeng, X.-A.; Liu, Y.-Y.; Xu, C.-H.; Sun, W.-W. Effects of pulsed electric field treatment on a bovine serum albumin-dextran model system, a means of promoting the Maillard reaction. Food Chem. 2010, 123, 275-280. [CrossRef]

21. Wang, Q.; Ismail, B. Effect of Maillard-induced glycosylation on the nutritional quality, solubility, thermal stability and molecular configuration of whey proteinv. Int. Dairy J. 2012, 25, 112-122. [CrossRef]

22. Doost, A.S.; Nasrabadi, M.N.; Goli, S.A.H.; van Troys, M.; Dubruel, P.; De Neve, N.; Van der Meeren, P. Maillard conjugation of whey protein isolate with water-soluble fraction of almond gum or flaxseed mucilage by dry heat treatment. Food Res. Int. 2020, 128, 108779. [CrossRef] [PubMed]

23. Pirestani, S.; Nasirpour, A.; Keramat, J.; Desobry, S.; Jasniewski, J. Structural properties of canola protein isolate-gum Arabic Maillard conjugate in an aqueous model system. Food Hydrocoll. 2018, 79, 228-234. [CrossRef]

24. Xu, Z.-Z.; Huang, G.-Q.; Xu, T.-C.; Liu, L.-N.; Xiao, J.-X. Comparative study on the Maillard reaction of chitosan oligosaccharide and glucose with soybean protein isolate. Int. J. Biol. Macromol. 2019, 131, 601-607. [CrossRef] [PubMed]

25. Ma, X.; Chen, W.; Yan, T.; Wang, D.; Hou, F.; Miao, S.; Liu, D. Comparison of citrus pectin and apple pectin in conjugation with soy protein isolate (SPI) under controlled dry-heating conditions. Food Chem. 2020, 309, 125501. [CrossRef] [PubMed]

26. Sheng, L.; Tang, G.; Wang, Q.; Zou, J.; Ma, M.; Huang, X. Molecular characteristics and foaming properties of ovalbumin-pullulan conjugates through the Maillard reaction. Food Hydrocoll. 2020, 100, 105384. [CrossRef]

27. Jiménez-Castaño, L.; Villamiel, M.; López-Fandiño, R. Glycosylation of individual whey proteins by Maillard reaction using dextran of different molecular mass. Food Hydrocoll. 2007, 21, 433-443. [CrossRef]

28. Al-Hakkak, J.; Al-Hakkak, F. Functional egg white-pectin conjugates prepared by controlled Maillard reaction. J. Food Eng. 2010, 100, 152-159. [CrossRef]

29. Wang, L.; Wu, M.; Liu, H.-M. Emulsifying and physicochemical properties of soy hull hemicelluloses-soy protein isolate conjugates. Carbohyd. Polym. 2017, 163, 181-190. [CrossRef]

30. Seo, C.W.; Yoo, B. Preparation of milk protein isolate/k-carrageenan conjugates by maillard reaction in wet-heating system and their application to stabilization of oil-in-water emulsions. LWT 2021, 139, 110542. [CrossRef]

31. Wen, C.; Zhang, J.; Qin, W.; Gu, J.; Zhang, H.; Duan, Y.; Ma, H. Structure and functional properties of soy protein isolatelentinan conjugates obtained in Maillard reaction by slit divergent ultrasonic assisted wet heating and the stability of oil-in-water emulsions. Food Chem. 2020, 331, 127374. [CrossRef] [PubMed]

32. Ma, X.; Hou, F.; Zhao, H.; Wang, D.; Chen, W.; Miao, S.; Liu, D. Conjugation of soy protein isolate (SPI) with pectin by ultrasound treatment. Food Hydrocoll. 2020, 108, 106056. [CrossRef]

33. Jian, W.; He, J.; Sun, Y.; Pang, J. Comparative studies on physicochemical properties of bovine serum albumin-glucose and bovine serum albumin-mannose conjugates formed via Maillard reaction. LWT Food Sci. Technol. 2016, 69, 358-364. [CrossRef]

34. Zhou, Y.; Niu, H.; Luo, T.; Yun, Y.; Zhang, M.; Chen, W.; Zhong, Q.; Zhang, H.; Chen, H.; Chen, W. Effect of glycosylation with sugar beet pectin on the interfacial behaviour and emulsifying ability of coconut protein. Int. J. Biol. Macromol. 2021, 183, 1621-1629. [CrossRef] [PubMed]

35. Li, Z.; Zheng, Y.; Sun, Q.; Wang, J.; Zheng, B.; Guo, Z. Structural characteristics and emulsifying properties of myofibrillar protein-dextran conjugates induced by ultrasound Maillard reaction. Ultrason. Sonochem. 2021, 72, 105458. [CrossRef]

36. Warnakulasuriya, S.N.; Nickerson, M.T. Review on plant protein-polysaccharide complex coacervation, and the functionality and applicability of formed complexes. J. Sci. Food Agric. 2018, 98, 5559-5571. [CrossRef]

37. Li, Y.; Zhang, X.; Zhao, Y.; Ding, J.; Lin, S. Investigation on complex coacervation between fish skin gelatin from cold-water fish and gum arabic: Phase behavior, thermodynamic, and structural properties. Food Res. Int. 2018, 107, 596-604. [CrossRef]

38. Eghbal, N.; Yarmand, M.S.; Mousavi, M.; Degraeve, P.; Oulahal, N.; Gharsallaoui, A. Complex coacervation for the development of composite edible films based on LM pectin and sodium caseinate. Carbohyd. Polym. 2016, 151, 947-956. [CrossRef]

39. Dong, D.; Hua, Y. Glycinin-gum arabic complex formation: Turbidity measurement and charge neutralization analysis. Food Res. Int. 2016, 89, 709-715. [CrossRef]

40. Pillai, P.K.S.; Stone, A.K.; Guo, Q.; Guo, Q.; Wang, Q.; Nickerson, M.T. Effect of alkaline de-esterified pectin on the complex coacervation with pea protein isolate under different mixing conditions. Food Chem. 2019, 284, 227-235. [CrossRef]

41. Zinoviadou, K.G.; Scholten, E.; Moschakis, T.; Biliaderis, C.G. Properties of emulsions stabilised by sodium caseinate-chitosan complexes. Int. Dairy J. 2012, 26, 94-101. [CrossRef] 
42. Souza, C.J.F.; Garcia-Rojas, E.E. Interpolymeric complexing between egg white proteins and xanthan gum: Effect of salt and protein/polysaccharide ratio. Food Hydrocoll. 2017, 66, 268-275. [CrossRef]

43. Souza, C.J.F.; da Costa, A.R.; Souza, C.F.; Tosin, F.F.S.; Garcia-Rojas, E.E. Complex coacervation between lysozyme and pectin: Effect of $\mathrm{pH}$, salt, and biopolymer ratio. Int. J. Biol. Macromol. 2018, 107, 1253-1260. [CrossRef] [PubMed]

44. Wang, X.; Lee, J.; Wang, Y.-W.; Huang, Q. Composition and rheological properties of $\beta$-lactoglobulin/pectin coacervates: Effects of salt concentration and initial protein/polysaccharide ratio. Biomacromolecules 2007, 8, 992-997. [CrossRef] [PubMed]

45. Ghorbani Gorji, E.; Waheed, A.; Ludwig, R.; Toca-Herrera, J.L.; Schleining, G.; Ghorbani Gorji, S. Complex Coacervation of Milk Proteins with Sodium Alginate. J. Agr. Food Chem. 2018, 66, 3210-3220. [CrossRef] [PubMed]

46. Dong, D.; Cui, B. Comparison of rheological properties of different protein/gum arabic complex coacervates. J. Food Process Eng. 2019, 42, e13196. [CrossRef]

47. Hasanvand, E.; Rafe, A. Rheological and structural properties of rice bran protein-flaxseed (Linum usitatissimum L.) gum complex coacervates. Food Hydrocoll. 2018, 83, 296-307. [CrossRef]

48. Souza, C.J.F.; Souza, C.S.F.; Heckert Bastos, L.P.; Garcia-Rojas, E.E. Interpolymer complexation of egg white proteins and carrageenan: Phase behavior, thermodynamics and rheological properties. Int. J. Biol. Macromol. 2018, 109, 467-475. [CrossRef]

49. Hu, J.; Zhao, T.; Li, S.; Wang, Z.; Wen, C.; Wang, H.; Yu, C.; Ji, C. Stability, microstructure, and digestibility of whey protein isolate-Tremella fuciformis polysaccharide complexes. Food Hydrocoll. 2019, 89, 379-385. [CrossRef]

50. Derkach, S.R.; Kuchina, Y.A.; Kolotova, D.S.; Voron'ko, N.G. Polyelectrolyte Polysaccharide-Gelatin Complexes: Rheology and Structure. Polymers 2020, 12, 266. [CrossRef]

51. Xu, A.Y.; Melton, L.D.; Ryan, T.M.; Mata, J.P.; Rekas, A.; Williams, M.A.K.; McGillivray, D.J. Effects of polysaccharide charge pattern on the microstructures of $\beta$-lactoglobulin-pectin complex coacervates, studied by SAXS and SANS. Food Hydrocoll. 2018, 77, 952-963. [CrossRef]

52. Jin, W.; Wang, Z.; Peng, D.; Shen, W.; Zhu, Z.; Cheng, S.; Li, B.; Huang, Q. Effect of pulsed electric field on assembly structure of $\alpha$-amylase and pectin electrostatic complexes. Food Hydrocoll. 2020, 101, 105547. [CrossRef]

53. Yang, Y.; Cui, S.; Gong, J.; Miller, S.S.; Wang, Q.; Hua, Y. Stability of citral in oil-in-water emulsions protected by a soy proteinpolysaccharide Maillard reaction product. Food Res. Int. 2015, 69, 357-363. [CrossRef]

54. Araiza-Calahorra, A.; Akhtar, M.; Sarkar, A. Recent advances in emulsion-based delivery approaches for curcumin: From encapsulation to bioaccessibility. Trends Food Sci. Technol. 2018, 71, 155-169. [CrossRef]

55. Zhang, F.; Cai, X.; Ding, L.; Wang, S. Effect of $\mathrm{pH}$, ionic strength, chitosan deacetylation on the stability and rheological properties of $\mathrm{O} / \mathrm{W}$ emulsions formulated with chitosan/casein complexes. Food Hydrocoll. 2021, 111, 106211. [CrossRef]

56. Zha, F.; Dong, S.; Rao, J.; Chen, B. Pea protein isolate-gum Arabic Maillard conjugates improves physical and oxidative stability of oil-in-water emulsions. Food Chem. 2019, 285, 130-138. [CrossRef] [PubMed]

57. Jaiswal, M.; Dudhe, R.; Sharma, P. Nanoemulsion: An advanced mode of drug delivery system. 3 Biotech 2015, 5, 123-127. [CrossRef]

58. Yin, B.; Deng, W.; Xu, K.; Huang, L.; Yao, P. Stable nano-sized emulsions produced from soy protein and soy polysaccharide complexes. J. Colloid Interf. Sci. 2012, 380, 51-59. [CrossRef]

59. Liu, Q.-R.; Qi, J.-R.; Yin, S.-W.; Wang, J.-M.; Guo, J.; Feng, J.-L.; Cheng, M.; Cao, J.; Weng, J.-Y.; Yang, X.-Q. The influence of heat treatment on acid-tolerant emulsions prepared from acid soluble soy protein and soy soluble polysaccharide complexes. Food Res. Int. 2016, 89, 211-218. [CrossRef]

60. Khan, A.Y.; Talegaonkar, S.; Iqbal, Z.; Ahmed, F.J.; Khar, R.K. Multiple emulsions: An overview. Curr. Drug Deliv. 2006, 3, 429-443. [CrossRef]

61. Pimentel-Moral, S.; Ochando-Pulido, J.M.; Segura-Carretero, A.; Martinez-Ferez, A. Stabilization of W/O/W multiple emulsion loaded with Hibiscus sabdariffa extract through protein-polysaccharide complexes. LWT 2018, 90, 389-395. [CrossRef]

62. Li, B.; Jiang, Y.; Liu, F.; Chai, Z.; Li, Y.; Li, Y.; Leng, X. Synergistic effects of whey protein-polysaccharide complexes on the controlled release of lipid-soluble and water-soluble vitamins in $\mathrm{W}_{1} / \mathrm{O} / \mathrm{W}_{2}$ double emulsion systems. Int. J. Food Sci. Technol. 2012, 47, 248-254. [CrossRef]

63. O'Regan, J.; Mulvihill, D.M. Sodium caseinate-maltodextrin conjugate stabilized double emulsions: Encapsulation and stability. Food Res. Int. 2010, 43, 224-231. [CrossRef]

64. Esfanjani, A.F.; Jafari, S.M.; Assadpour, E. Preparation of a multiple emulsion based on pectin-whey protein complex for encapsulation of saffron extract nanodroplets. Food Chem. 2017, 221, 1962-1969. [CrossRef] [PubMed]

65. Gharehbeglou, P.; Jafari, S.M.; Hamishekar, H.; Homayouni, A.; Mirzaei, H. Pectin-whey protein complexes vs. small molecule surfactants for stabilization of double nano-emulsions as novel bioactive delivery systems. J. Food Eng. 2019, 245, 139-148. [CrossRef]

66. Burgos-Díaz, C.; Wandersleben, T.; Marqués, A.M.; Rubilar, M. Multilayer emulsions stabilized by vegetable proteins and polysaccharides. Curr. Opin. Colloid Interface Sci. 2016, 25, 51-57. [CrossRef]

67. Shamsara, O.; Jafari, S.M.; Muhidinov, Z.K. Development of double layered emulsion droplets with pectin/ $\beta$-lactoglobulin complex for bioactive delivery purposes. J. Mol. Liq. 2017, 243, 144-150. [CrossRef]

68. Albert, C.; Beladjine, M.; Tsapis, N.; Fattal, E.; Agnely, F.; Huang, N. Pickering emulsions: Preparation processes, key parameters governing their properties and potential for pharmaceutical applications. J. Control Release 2019, 309, 302-332. [CrossRef] 
69. Santos, J.; Alcaide-González, M.A.; Trujillo-Cayado, L.A.; Carrillo, F.; Alfaro-Rodríguez, M.C. Development of food-grade Pickering emulsions stabilized by a biological macromolecule (xanthan gum) and zein. Int. J. Biol. Macromol. 2020, 153, 747-754. [CrossRef]

70. Wei, Z.; Huang, Q. Edible Pickering emulsions stabilized by ovotransferrin-gum arabic particles. Food Hydrocoll. $2019,89,590-601$. [CrossRef]

71. Lengyel, M.; Kállai-Szabó, N.; Antal, V.; Laki, A.J.; Antal, I. Microparticles, microspheres, and microcapsules for advanced drug delivery. Sci. Pharm. 2019, 87, 20. [CrossRef]

72. Timilsena, Y.P.; Adhikari, R.; Barrow, C.J.; Adhikari, B. Digestion behaviour of chia seed oil encapsulated in chia seed protein-gum complex coacervates. Food Hydrocoll. 2017, 66, 71-81. [CrossRef]

73. Jia, C.; Cao, D.; Ji, S.; Lin, W.; Zhang, X.; Muhoza, B. Whey protein isolate conjugated with xylo-oligosaccharides via maillard reaction: Characterization, antioxidant capacity, and application for lycopene microencapsulation. LWT 2020, $118,108837$. [CrossRef]

74. Du, Y.-L.; Huang, G.-Q.; Wang, H.-O.; Xiao, J.-X. Effect of high coacervation temperature on the physicochemical properties of resultant microcapsules through induction of Maillard reaction between soybean protein isolate and chitosan. J. Food Eng. 2018, 234, 91-97. [CrossRef]

75. Shaddel, R.; Hesari, J.; Azadmard-Damirchi, S.; Hamishehkar, H.; Fathi-Achachlouei, B.; Huang, Q. Use of gelatin and gum Arabic for encapsulation of black raspberry anthocyanins by complex coacervation. Int. J. Biol. Macromol. 2018, 107, 1800-1810. [CrossRef]

76. Ozel, B.; Cikrikci, S.; Aydin, O.; Oztop, M.H. Polysaccharide blended whey protein isolate-(WPI) hydrogels: A physicochemical and controlled release study. Food Hydrocoll. 2017, 71, 35-46. [CrossRef]

77. Le, X.T.; Rioux, L.-E.; Turgeon, S.L. Formation and functional properties of protein-polysaccharide electrostatic hydrogels in comparison to protein or polysaccharide hydrogels. Adv. Colloid Interface Sci. 2017, 239, 127-135. [CrossRef]

78. Pei, Y.; Li, Z.; McClements, D.J.; Li, B. Comparison of structural and physicochemical properties of lysozyme/carboxymethylcellulose complexes and microgels. Food Res. Int. 2019, 122, 273-282. [CrossRef]

79. Jiang, Y.; Chen, J.; Deng, C.; Suuronen, E.J.; Zhong, Z. Click hydrogels, microgels and nanogels: Emerging platforms for drug delivery and tissue engineering. Biomaterials 2014, 35, 4969-4985. [CrossRef]

80. Zhou, M.; Wang, T.; Hu, Q.; Luo, Y. Low density lipoprotein/pectin complex nanogels as potential oral delivery vehicles for curcumin. Food Hydrocoll. 2016, 57, 20-29. [CrossRef]

81. Ding, X.; Yao, P. Soy protein/soy polysaccharide complex nanogels: Folic acid loading, protection, and controlled delivery. Langmuir 2013, 29, 8636-8644. [CrossRef] [PubMed]

82. Jin, B.; Zhou, X.; Li, X.; Lin, W.; Chen, G.; Qiu, R. Self-assembled modified soy protein/dextran nanogel induced by ultrasonication as a delivery vehicle for riboflavin. Molecules 2016, 21, 282. [CrossRef]

83. Huang, X.; Huang, X.; Gong, Y.; Xiao, H.; McClements, D.J.; Hu, K. Enhancement of curcumin water dispersibility and antioxidant activity using core-shell protein-polysaccharide nanoparticles. Food Res. Int. 2016, 87, 1-9. [CrossRef]

84. Wei, Y.; Sun, C.; Dai, L.; Zhan, X.; Gao, Y. Structure, physicochemical stability and in vitro simulated gastrointestinal digestion properties of $\beta$-carotene loaded zein-propylene glycol alginate composite nanoparticles fabricated by emulsification-evaporation method. Food Hydrocoll. 2018, 81, 149-158. [CrossRef]

85. Chen, G.; Dong, S.; Chen, Y.; Gao, Y.; Zhang, Z.; Li, S.; Chen, Y. Complex coacervation of zein-chitosan via atmospheric cold plasma treatment: Improvement of encapsulation efficiency and dispersion stability. Food Hydrocoll. 2020, 107, 105943. [CrossRef]

86. Muhoza, B.; Xia, S.; Wang, X.; Zhang, X.; Li, Y.; Zhang, S. Microencapsulation of essential oils by complex coacervation method: Preparation, thermal stability, release properties and applications. Crit. Rev. Food Sci. Nutr. 2020, 1-20. [CrossRef] [PubMed]

87. Xu, G.; Li, L.; Bao, X.; Yao, P. Curcumin, casein and soy polysaccharide ternary complex nanoparticles for enhanced dispersibility, stability and oral bioavailability of curcumin. Food Biosci. 2020, 35, 100569. [CrossRef]

88. Ren, D.; Qi, J.; Xie, A.; Jia, M.; Yang, X.; Xiao, H. Encapsulation in lysozyme/A. Sphaerocephala Krasch polysaccharide nanoparticles increases stability and bioefficacy of curcumin. J. Funct. Foods 2017, 38, 100-109. [CrossRef]

89. Wei, Y.; Cai, Z.; Wu, M.; Guo, Y.; Wang, P.; Li, R.; Ma, A.; Zhang, H. Core-shell pea protein-carboxymethylated corn fiber gum composite nanoparticles as delivery vehicles for curcumin. Carbohyd. Polym. 2020, 240, 116273. [CrossRef] [PubMed]

90. Guo, Q.; Su, J.; Xie, W.; Tu, X.; Yuan, F.; Mao, L.; Gao, Y. Curcumin-loaded pea protein isolate-high methoxyl pectin complexes induced by calcium ions: Characterization, stability and in vitro digestibility. Food Hydrocoll. 2020, 98, 105284. [CrossRef]

91. Okagu, O.D.; Verma, O.; McClements, D.J.; Udenigwe, C.C. Utilization of insect proteins to formulate nutraceutical delivery systems: Encapsulation and release of curcumin using mealworm protein-chitosan nano-complexes. Int. J. Biol. Macromol. 2020, 151, 333-343. [CrossRef] [PubMed]

92. Sarika, P.R.; James, N.R. Polyelectrolyte complex nanoparticles from cationised gelatin and sodium alginate for curcumin delivery. Carbohyd. Polym. 2016, 148, 354-361. [CrossRef]

93. Mohammadian, M.; Salami, M.; Alavi, F.; Momen, S.; Emam-Djomeh, Z.; Moosavi-Movahedi, A.A. Fabrication and Characterization of Curcumin-Loaded Complex Coacervates Made of Gum Arabic and Whey Protein Nanofibrils. Food Biophys. 2019, 14, 425-436. [CrossRef] 
94. Li, Z.; Wang, Y.; Pei, Y.; Xiong, W.; Zhang, C.; Xu, W.; Liu, S.; Li, B. Curcumin encapsulated in the complex of lysozyme/carboxymethylcellulose and implications for the antioxidant activity of curcumin. Food Res. Int. 2015, 75, 98-105. [CrossRef] [PubMed]

95. Yi, J.; Peng, G.; Zheng, S.; Wen, Z.; Gan, C.; Fan, Y. Fabrication of whey protein isolate-sodium alginate nanocomplex for curcumin solubilization and stabilization in a model fat-free beverage. Food Chem. 2021, 348, 129102. [CrossRef]

96. Xie, H.; Xiang, C.; Li, Y.; Wang, L.; Zhang, Y.; Song, Z.; Ma, X.; Lu, X.; Lei, Q.; Fang, W. Fabrication of ovalbumin/ k-carrageenan complex nanoparticles as a novel carrier for curcumin delivery. Food Hydrocoll. 2019, 89, 111-121. [CrossRef]

97. Zhang, H.; Jiang, L.; Tong, M.; Lu, Y.; Ouyang, X.-K.; Ling, J. Encapsulation of curcumin using fucoidan stabilized zein nanoparticles: Preparation, characterization, and in vitro release performance. J. Mol. Liq. 2021, 329, 115586. [CrossRef]

98. Yan, J.-K.; Qiu, W.-Y.; Wang, Y.-Y.; Wu, J.-Y. Biocompatible Polyelectrolyte Complex Nanoparticles from Lactoferrin and Pectin as Potential Vehicles for Antioxidative Curcumin. J. Agr. Food Chem. 2017, 65, 5720-5730. [CrossRef]

99. Xu, G.; Wang, C.; Yao, P. Stable emulsion produced from casein and soy polysaccharide compacted complex for protection and oral delivery of curcumin. Food Hydrocoll. 2017, 71, 108-117. [CrossRef]

100. Wang, C.; Liu, Z.; Xu, G.; Yin, B.; Yao, P. BSA-dextran emulsion for protection and oral delivery of curcumin. Food Hydrocoll. 2016, 61, 11-19. [CrossRef]

101. Meena, S.; Prasad, W.; Khamrui, K.; Mandal, S.; Bhat, S. Preparation of spray-dried curcumin microcapsules using a blend of whey protein with maltodextrin and gum arabica and its in-vitro digestibility evaluation. Food Biosci. 2021, 41, 100990. [CrossRef]

102. Su, J.; Cai, Y.; Zhi, Z.; Guo, Q.; Mao, L.; Gao, Y.; Yuan, F.; Van der Meeren, P. Assembly of propylene glycol alginate/ $\beta$-lactoglobulin composite hydrogels induced by ethanol for co-delivery of probiotics and curcumin. Carbohyd. Polym. 2021, 254, 117446. [CrossRef] [PubMed]

103. Liu, Y.; Gao, L.; Yi, J.; Fan, Y.; Wu, X.; Zhang, Y. $\alpha$-Lactalbumin and chitosan core-shell nanoparticles: Resveratrol loading, protection, and antioxidant activity. Food Funct. 2020, 11, 1525-1536. [CrossRef]

104. Khan, M.A.; Yue, C.; Fang, Z.; Hu, S.; Cheng, H.; Bakry, A.M.; Liang, L. Alginate/chitosan-coated zein nanoparticles for the delivery of resveratrol. J. Food Eng. 2019, 258, 45-53. [CrossRef]

105. Khan, M.A.; Chen, L.; Liang, L. Improvement in storage stability and resveratrol retention by fabrication of hollow zein-chitosan composite particles. Food Hydrocoll. 2021, 113, 106477. [CrossRef]

106. Huang, X.; Dai, Y.; Cai, J.; Zhong, N.; Xiao, H.; McClements, D.J.; Hu, K. Resveratrol encapsulation in core-shell biopolymer nanoparticles: Impact on antioxidant and anticancer activities. Food Hydrocoll. 2017, 64, 157-165. [CrossRef]

107. Consoli, L.; Dias, R.A.O.; Rabelo, R.S.; Furtado, G.F.; Sussulini, A.; Cunha, R.L.; Hubinger, M.D. Sodium caseinate-corn starch hydrolysates conjugates obtained through the Maillard reaction as stabilizing agents in resveratrol-loaded emulsions. Food Hydrocoll. 2018, 84, 458-472. [CrossRef]

108. Acevedo-Fani, A.; Silva, H.D.; Soliva-Fortuny, R.; Martín-Belloso, O.; Vicente, A.A. Formation, stability and antioxidant activity of food-grade multilayer emulsions containing resveratrol. Food Hydrocoll. 2017, 71, 207-215. [CrossRef]

109. Raei, M.; Shahidi, F.; Farhoodi, M.; Jafari, S.M.; Rafe, A. Application of whey protein-pectin nano-complex carriers for loading of lactoferrin. Int. J. Biol. Macromol. 2017, 105, 281-291. [CrossRef]

110. Mendanha, D.V.; Ortiz, S.E.M.; Favaro-Trindade, C.S.; Mauri, A.; Monterrey-Quintero, E.S.; Thomazini, M. Microencapsulation of casein hydrolysate by complex coacervation with SPI/pectin. Food Res. Int. 2009, 42, 1099-1104. [CrossRef]

111. Jo, Y.-J.; van der Schaaf, U.S. Fabrication and characterization of double $\left(\mathrm{W}_{1} / \mathrm{O} / \mathrm{W}_{2}\right)$ emulsions loaded with bioactive peptide/polysaccharide complexes in the internal water $\left(\mathrm{W}_{1}\right)$ phase for controllable release of bioactive peptide. Food Chem. 2021, 344, 128619. [CrossRef] [PubMed]

112. Xu, Y.; Ma, X.-Y.; Gong, W.; Li, X.; Huang, H.-B.; Zhu, X.-M. Nanoparticles based on carboxymethylcellulose-modified rice protein for efficient delivery of lutein. Food Funct. 2020, 11, 2380-2394. [CrossRef]

113. Li, H.; Yuan, Y.; Zhu, J.; Wang, T.; Wang, D.; Xu, Y. Zein/soluble soybean polysaccharide composite nanoparticles for encapsulation and oral delivery of lutein. Food Hydrocoll. 2020, 103, 105715. [CrossRef]

114. Morales, E.A.C.; Doost, A.S.; Velazquez, G.; Van der Meeren, P. Comparison of low-and high-methoxyl pectin for the stabilization of whey protein isolate as carrier for lutein. Food Hydrocoll. 2021, 113, 106458. [CrossRef]

115. Gumus, C.E.; Davidov-Pardo, G.; McClements, D.J. Lutein-enriched emulsion-based delivery systems: Impact of Maillard conjugation on physicochemical stability and gastrointestinal fate. Food Hydrocoll. 2016, 60, 38-49. [CrossRef]

116. Xu, L.; Wang, J.; Su, Y.; Chang, C.; Gu, L.; Yang, Y.; Li, J. Utilization of high internal phase emulsion stabilized by egg yolk-modified starch complex for the delivery of lutein. LWT 2021, 142, 111024. [CrossRef]

117. Su, J.; Guo, Q.; Chen, Y.; Dong, W.; Mao, L.; Gao, Y.; Yuan, F. Characterization and formation mechanism of lutein pickering emulsion gels stabilized by $\beta$-lactoglobulin-gum arabic composite colloidal nanoparticles. Food Hydrocoll. 2020, 98,105276 [CrossRef]

118. Wang, Y.; Gan, J.; Li, Y.; Nirasawa, S.; Cheng, Y. Conformation and emulsifying properties of deamidated wheat glutenmaltodextrin/citrus pectin conjugates and their abilities to stabilize $\beta$-carotene emulsions. Food Hydrocoll. 2019, 87, 129-141. [CrossRef]

119. Hu, Q.; Wu, Y.; Zhong, L.; Ma, N.; Zhao, L.; Ma, G.; Cheng, N.; Nakata, P.A.; Xu, J. In vitro digestion and cellular antioxidant activity of $\beta$-carotene-loaded emulsion stabilized by soy protein isolate-Pleurotus eryngii polysaccharide conjugates. Food Hydrocoll. 2021, 112, 106340. [CrossRef] 
120. Zhong, L.; Ma, N.; Wu, Y.; Zhao, L.; Ma, G.; Pei, F.; Hu, Q. Gastrointestinal fate and antioxidation of $\beta$-carotene emulsion prepared by oat protein isolate-Pleurotus ostreatus $\beta$-glucan conjugate. Carbohyd. Polym. 2019, 221, 10-20. [CrossRef]

121. López-Monterrubio, D.; Lobato-Calleros, C.; Vernon-Carter, E.; Alvarez-Ramirez, J. Influence of $\beta$-carotene concentration on the physicochemical properties, degradation and antioxidant activity of nanoemulsions stabilized by whey protein hydrolyzate-pectin soluble complexes. LWT 2021, 111148. [CrossRef]

122. Yi, J.; Gan, C.; Wen, Z.; Fan, Y.; Wu, X. Development of pea protein and high methoxyl pectin colloidal particles stabilized high internal phase pickering emulsions for $\beta$-carotene protection and delivery. Food Hydrocoll. 2021, 113, 106497. [CrossRef]

123. Silva, D.; Favaro-Trindade, C.; Rocha, G.; Thomazini, M. Microencapsulation of lycopene by gelatin-pectin complex coacervation. J. Food Process. Pres. 2012, 36, 185-190. [CrossRef]

124. Assadpour, E.; Maghsoudlou, Y.; Jafari, S.-M.; Ghorbani, M.; Aalami, M. Optimization of folic acid nano-emulsification and encapsulation by maltodextrin-whey protein double emulsions. Int. J. Biol. Macromol. 2016, 86, 197-207. [CrossRef] [PubMed]

125. Assadpour, E.; Jafari, S.-M.; Maghsoudlou, Y. Evaluation of folic acid release from spray dried powder particles of pectin-whey protein nano-capsules. Int. J. Biol. Macromol. 2017, 95, 238-247. [CrossRef] [PubMed]

126. Xiang, C.; Gao, J.; Ye, H.; Ren, G.; Ma, X.; Xie, H.; Fang, S.; Lei, Q.; Fang, W. Development of ovalbumin-pectin nanocomplexes for vitamin D3 encapsulation: Enhanced storage stability and sustained release in simulated gastrointestinal digestion. Food Hydrocoll. 2020, 106, 105926. [CrossRef]

127. Kazemi-Taskooh, Z.; Varidi, M. Designation and characterization of cold-set whey protein-gellan gum hydrogel for iron entrapment. Food Hydrocoll. 2021, 111, 106205. [CrossRef]

128. Yao, X.; Xu, K.; Shu, M.; Liu, N.; Li, N.; Chen, X.; Nishinari, K.; Phillips, G.O.; Jiang, F. Fabrication of iron loaded whey protein isolate/gum Arabic nanoparticles and its adsorption activity on oil-water interface. Food Hydrocoll. 2021, 115, 106610. [CrossRef]

129. Singla, R.K.; Dubey, A.K.; Garg, A.; Sharma, R.K.; Fiorino, M.; Ameen, S.M.; Haddad, M.A.; Al-Hiary, M. Natural Polyphenols: Chemical Classification, Definition of Classes, Subcategories, and Structures. J. AOAC Int. 2019, 102, 1397-1400. [CrossRef]

130. Zhang, X.; Zeng, Q.; Liu, Y.; Cai, Z. Enhancing the resistance of anthocyanins to environmental stress by constructing ovalbuminpropylene glycol alginate nanocarriers with novel configurations. Food Hydrocoll. 2021, 118, 106668. [CrossRef]

131. Cuevas-Bernardino, J.C.; Leyva-Gutierrez, F.M.; Vernon-Carter, E.J.; Lobato-Calleros, C.; Román-Guerrero, A.; Davidov-Pardo, G. Formation of biopolymer complexes composed of pea protein and mesquite gum-Impact of quercetin addition on their physical and chemical stability. Food Hydrocoll. 2018, 77, 736-745. [CrossRef]

132. Li, H.; Wang, D.; Liu, C.; Zhu, J.; Fan, M.; Sun, X.; Wang, T.; Xu, Y.; Cao, Y. Fabrication of stable zein nanoparticles coated with soluble soybean polysaccharide for encapsulation of quercetin. Food Hydrocoll. 2019, 87, 342-351. [CrossRef]

133. Li, J.; Yang, X.; Li, X.; Zhang, Z.; Wei, Z.; Xing, Z.; Deng, S.; Duan, F. Okra polysaccharides/gelatin complex coacervate as $\mathrm{pH}$-responsive and intestine-targeting delivery protects isoquercitin bioactivity. Int. J. Biol. Macromol. 2020, 159, $487-496$. [CrossRef] [PubMed]

134. Chen, S.; Han, Y.; Wang, Y.; Yang, X.; Sun, C.; Mao, L.; Gao, Y. Zein-hyaluronic acid binary complex as a delivery vehicle of quercetagetin: Fabrication, structural characterization, physicochemical stability and in vitro release property. Food Chem. 2019, 276, 322-332. [CrossRef] [PubMed]

135. Chen, W.; Lv, R.; Muhammad, A.I.; Guo, M.; Ding, T.; Ye, X.; Liu, D. Fabrication of (-)-epigallocatechin-3-gallate carrier based on glycosylated whey protein isolate obtained by ultrasound Maillard reaction. Ultrason. Sonochem. 2019, 58, 104678. [CrossRef]

136. Fan, L.; Lu, Y.; Ouyang, X.-K.; Ling, J. Development and characterization of soybean protein isolate and fucoidan nanoparticles for curcumin encapsulation. Int. J. Biol. Macromol. 2021, 169, 194-205. [CrossRef]

137. Hewlings, S.J.; Kalman, D.S. Curcumin: A review of its effects on human health. Foods 2017, 6, 92. [CrossRef]

138. Okagu, O.D.; Jin, J.; Udenigwe, C.C. Impact of succinylation on pea protein-curcumin interaction, polyelectrolyte complexation with chitosan, and gastrointestinal release of curcumin in loaded-biopolymer nano-complexes. J. Mol. Liq. 2021, 325, 115248. [CrossRef]

139. Yi, J.; Fan, Y.; Zhang, Y.; Wen, Z.; Zhao, L.; Lu, Y. Glycosylated $\alpha$-lactalbumin-based nanocomplex for curcumin: Physicochemical stability and DPPH-scavenging activity. Food Hydrocoll. 2016, 61, 369-377. [CrossRef]

140. Cho, H.; Lee, H.J.; Yu, K.S.; Choi, Y.M.; Hwang, K.T. Characterisation and food application of curcumin bound to sodium caseinate-polysaccharide electrostatic complexes. Int. J. Food Sci. Technol. 2017, 52, 1770-1776. [CrossRef]

141. Cheng, H.; Zhang, H.; Li, D.; Duan, H.; Liang, L. Impact of oil type on the location, partition and chemical stability of resveratrol in oil-in-water emulsions stabilized by whey protein isolate plus gum Arabic. Food Hydrocoll. 2020, 109, 106119. [CrossRef]

142. Ren, X.; Hou, T.; Liang, Q.; Zhang, X.; Hu, D.; Xu, B.; Chen, X.; Chalamaiah, M.; Ma, H. Effects of frequency ultrasound on the properties of zein-chitosan complex coacervation for resveratrol encapsulation. Food Chem. 2019, 279, 223-230. [CrossRef] [PubMed]

143. Chakrabarti, S.; Guha, S.; Majumder, K. Food-derived bioactive peptides in human health: Challenges and opportunities. Nutrients 2018, 10, 1738. [CrossRef] [PubMed]

144. Udenigwe, C.C. Bioinformatics approaches, prospects and challenges of food bioactive peptide research. Trends Food Sci. Technol. 2014, 36, 137-143. [CrossRef]

145. Udenigwe, C.C.; Abioye, R.O.; Okagu, I.U.; Obeme-Nmom, J.I. Bioaccessibility of bioactive peptides: Recent advances and perspectives. Curr. Opin. Food Sci. 2021, 39, 182-189. [CrossRef] 
146. Saini, R.K.; Nile, S.H.; Park, S.W. Carotenoids from fruits and vegetables: Chemistry, analysis, occurrence, bioavailability and biological activities. Food Res. Int. 2015, 76, 735-750. [CrossRef] [PubMed]

147. Sun, J.; Liu, T.; Mu, Y.; Jing, H.; Obadi, M.; Xu, B. Enhancing the stabilization of $\beta$-carotene emulsion using ovalbumin-dextran conjugates as emulsifier. Colloids Surfaces A 2021, 626, 126806. [CrossRef]

148. Dhakal, S.P.; He, J. Microencapsulation of vitamins in food applications to prevent losses in processing and storage: A review. Food Res. Int. 2020, 137, 109326. [CrossRef]

149. Katouzian, I.; Jafari, S.M. Nano-encapsulation as a promising approach for targeted delivery and controlled release of vitamins. Trends Food Sci. Technol. 2016, 53, 34-48. [CrossRef]

150. Gao, J.; Liu, C.; Shi, J.; Ni, F.; Shen, Q.; Xie, H.; Wang, K.; Lei, Q.; Fang, W.; Ren, G. The regulation of sodium alginate on the stability of ovalbumin-pectin complexes for VD3 encapsulation and in vitro simulated gastrointestinal digestion study. Food Res. Int. 2021, 140, 110011. [CrossRef]

151. Sun, X.; Sarteshnizi, R.A.; Boachie, R.T.; Okagu, O.D.; Abioye, R.O.; Pfeilsticker Neves, R.; Ohanenye, I.C.; Udenigwe, C.C. Peptide-Mineral Complexes: Understanding Their Chemical Interactions, Bioavailability, and Potential Application in Mitigating Micronutrient Deficiency. Foods 2020, 9, 1402. [CrossRef] [PubMed] 